\title{
Moored observations of mesoscale features in the Cape Basin: characteristics and local impacts on water mass distributions
}

\author{
Marion Kersalé ${ }^{1,2,3}$, Tarron Lamont ${ }^{1,4}$, Sabrina Speich ${ }^{5}$, Thierry Terre ${ }^{6}$, Remi Laxenaire ${ }^{5}$, Mike J. Roberts ${ }^{4,7}$, \\ Marcel A. van den Berg ${ }^{4}$, and Isabelle J. Ansorge ${ }^{1}$ \\ ${ }^{1}$ Marine Research Institute, Department of Oceanography - University of Cape Town, Rondebosch, South Africa \\ ${ }^{2}$ Cooperative Institute for Marine and Atmospheric Studies, University of Miami, Miami, Florida, USA \\ ${ }^{3}$ NOAA/Atlantic Oceanographic and Meteorological Laboratory, Miami, Florida, USA \\ ${ }^{4}$ Oceans and Coastal Research, Department of Environmental Affairs, Cape Town, South Africa \\ ${ }^{5}$ Laboratoire de Météorologie Dynamique, UMR 8539 École Polytechnique, ENS, CNRS, Paris, France \\ ${ }^{6}$ IFREMER, Univ. Brest, CNRS, IRD, Laboratoire d'Océanographie Physique et Spatiale (LOPS), IUEM, Plouzané, France \\ ${ }^{7}$ Ocean Science \& Marine Food Security, Nelson Mandela University, Port Elizabeth, South Africa
}

Correspondence: Marion Kersalé (marion.kersale@noaa.gov)

Received: 11 October 2017 - Discussion started: 1 November 2017

Revised: 13 July 2018 - Accepted: 16 July 2018 - Published: 3 September 2018

\begin{abstract}
The eastern side of the South Atlantic Meridional overturning circulation Basin-wide Array (SAMBA) along $34.5^{\circ} \mathrm{S}$ is used to assess the nonlinear, mesoscale dynamics of the Cape Basin. This array presently consists of current meter moorings and bottom mounted Current and Pressure recording Inverted Echo Sounders (CPIES) deployed across the continental slope. These data, available from September 2014 to December 2015, combined with satellite altimetry allow us to investigate the characteristics and the impact of mesoscale dynamics on local water mass distribution and cross-validate the different data sets. We demonstrate that the moorings are affected by the complex dynamics of the Cape Basin involving Agulhas rings, cyclonic eddies and anticyclonic eddies from the Agulhas Bank and the South Benguela upwelling front and filaments. Our analyses show that exchange of water masses happens through the advection of water by mesoscale eddies but also via wide water mass intrusions engendered by the existence of intense dipoles. These complex dynamics induce strong intra-seasonal upperocean velocity variations and water mass exchanges between the shelf and the open ocean but also across the subantarctic and subtropical waters. This work presents the first independent observations comparison between full-depth moorings and CPIES data sets within the eastern South Atlantic region that gives some evidence of eastern boundary buoyancy anomalies associated with migrating eddies. It also high-
\end{abstract}

lights the need to continuously sample the full water depth as inter-basin exchanges occur intermittently and affect the whole water column.

\section{Introduction}

Mesoscale nonlinear dynamics contribute to large-scale water mass distribution and therefore to the large-scale Meridional Overturning Circulation (MOC) (Gordon, 1985; Biastoch et al., 2008; van Sebille et al., 2012), as they redistribute momentum, heat and mass between different regions (Robinson, 1983). Nonlinear mesoscale eddies, defined as nonlinear using the advective parameter criteria of Chelton et al. (2011), are found throughout the global oceans but are very energetic when associated with western boundary currents. The Agulhas Current, the intense western boundary current of the southern Indian Ocean, follows the African shelf edge southwestwards along the east coast. When it reaches the southern tip of Africa, at $34^{\circ} \mathrm{S}$, the Agulhas Current leaves the continental slope and affected by strong instabilities retroflects at $38^{\circ} \mathrm{S}$ into the Indian Ocean (Lutjeharms and Cooper, 1996; de Ruijter et al., 1999; Lutjeharms, 2006). These instabilities are responsible for extensive meandering just southwest of South Africa, and shear edge features such as Agulhas rings, eddies and filaments form within this re- 
gion. These nonlinear, mesoscale features control the Agulhas leakage - defined as the transport of warm and salty Indian Ocean waters into the Atlantic Ocean through the Cape Basin (labeled in Fig. 1; e.g., Gordon et al., 1992; de Ruijter et al., 1999). The Agulhas leakage injects buoyancy anomalies that impact the Atlantic MOC (AMOC) strength and the Atlantic Multi-decadal Oscillation, with clear implications for climate (e.g., Beal et al., 2011; Biastoch et al., 2015).

Agulhas ring observations, collected from shipboard surveys, were first exploited to quantify the energy, heat and salt fluxes of these mesoscale features (e.g., de Ruijter et al., 1999, and references therein). The first inter-ocean exchange estimates were based on individual hydrographic cruise data combined with altimetric tracking of Agulhas rings (Olson and Evans, 1986; Gordon and Haxby, 1990; Duncombe Rae, 1991; van Ballegooyen et al., 1994; Byrne et al., 1995). These combined data revealed the presence of four to eight rings per year propagating into the South Atlantic with speeds ranging between 5 and $10 \mathrm{~km} \mathrm{day}^{-1}$, with a diameter up to $400 \mathrm{~km}$, and their influence is felt from the surface down to an intermediate depth between 600 and $1100 \mathrm{~m}$. The associated inter-ocean volume transport per ring was estimated to be between 0.5 and $3 \mathrm{~Sv}\left(1 \mathrm{~Sv}=10^{6} \mathrm{~m}^{3} \mathrm{~s}^{-1}\right)$. These first estimates were based on statistics from the early constellation of altimetry satellites that resolved fewer features than the modern constellation and individual ring observations, which led to a large spread of documented volume flux estimates.

A more accurate estimate of the fluxes in the Cape Basin has been accomplished by deploying a line of instruments across the pathway of Agulhas rings (BEST Benguela Sources and Transport Experiment: Duncombe Rae et al., 1996; Garzoli and Gordon, 1996; Goni et al., 1997) and deep profiling floats (KAPEX - Cape of Good Hope Experiments: Lutjeharms et al., 1997; Richardson et al., 2003; MARE - Mixing of Agulhas Rings Experiment: van Aken et al., 2003). From these experiments, the northwestward propagation of the rings in the Cape Basin was characterized through a narrow ring corridor (Garzoli and Gordon, 1996) or through three different routes on the basis of topographic effects (Dencausse et al., 2010). Such measurements have also demonstrated the highly turbulent regime of the Cape Basin and the coexistence of cyclonic and anticyclonic eddies which can enhance horizontal mixing at intermediate depth (Boebel et al., 2003; Matano and Beier, 2003; Richardson and Garzoli, 2003; Hall and Lutjeharms, 2011; Arhan et al., 2011). Cyclonic eddies are about $50 \mathrm{~km}$ in diameter and are formed along the western coast of South Africa or inshore of the Agulhas Current (Lutjeharms et al., 2003). Tracked from altimetric data, recirculating plumes of warm water at the sea surface are often identified around these eddies.

The presence of several Agulhas rings and cyclonic eddies can induce the generation of dipole structures comparable to the Heton model of Hogg and Stommel (1985). These oceanic dipoles have been observed using satellite imagery

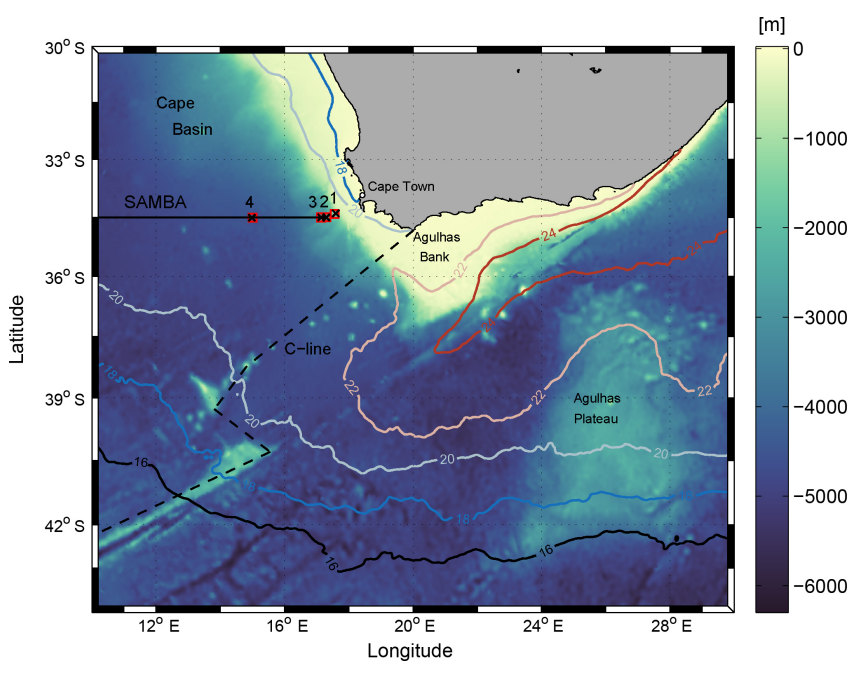

Figure 1. Study area with shaded color representing the bathymetry (m) from ETOPO1. The thin black line denotes the position of the SAMBA-east transect and the black crosses (red squares) represent the mooring (CPIES) positions with their associated numbers $(1,2$, 3 and 4). The dotted black line denotes the C-line position. Annually averaged 2015 SST isotherms from the ODYSSEA data set are plotted with colored contours.

thanks to their surface signature, described as a mushroomlike pattern in various regions, and have been characterized with numerical simulations and analytical theories (Ahlnäs et al., 1987; Hooker and Brown, 1994; Hooker et al., 1995; Millot and Taupier-Letage, 2005; Pallàs-Sanz and Viúdez, 2007; Baker-Yeboah et al., 2010a). These counterrotating eddies enhance horizontal transport of heat along isopycnals, particularly across frontal structures (Spall, 1995) and vertical diapycnal mixing. Related to dipole dynamics, filaments extending well below the thermocline (de Steur et al., 2004) have been observed during hydrographic cruises southwest of Madagascar and in the Cape Basin (de Ruijter et al., 2004; Whittle et al., 2008).

The mesoscale features in the Cape Basin can also interact with the eastern boundary flow regime (Dencausse et al., 2010). The connection between Agulhas rings and the South Benguela upwelling frontal zone has been evidenced by the propagation of cold filaments from the coastal upwelling system extending hundreds of kilometers offshore the Cape Peninsula (Duncombe Rae et al., 1992; Lutjeharms and Cooper, 1996). Eventually joining this coastal upwelling front, Agulhas filaments, originating from the Agulhas Current, have been observed in the upper part of the water column (Lutjeharms and Cooper, 1996). They have been associated with a strong equatorward front jet, the Cape Peninsula jet (Bang, 1973; Gordon, 1986; Lutjeharms and Meeuwis, 1987; Nelson et al., 1998). This strong equatorward jet is located over the shelf-break, with a width of $20-30 \mathrm{~km}$ and can reach a maximum velocity of $1.2 \mathrm{~m} \mathrm{~s}^{-1}$ (Shannon and Nelson, 1996; Veitch et al., 2017). Its dynamics are suggested to 
be linked with the local wind forcing during the upwelling season. However, this seasonality is still a subject of discussion as Boyd et al. (1992) show the occurrence of the jet beyond the upwelling season. This jet has been also linked to anticyclonic circulations associated with frequent passages of Agulhas rings along the continental slope (Dencausse et al., 2010). The issue is further complicated by the regular generation of cyclonic eddies against the continental slope in the area (Penven et al., 2001). These cyclonic eddies have been recently associated with the intensification of a poleward undercurrent that is generally weak to nonexistent in the Cape Basin (Baker-Yeboah et al., 2010b).

Understanding the Cape Basin circulation in the context of this strong nonlinear, mesoscale variability is crucial for many studies. On regional scales, the circulation is important for water mass distribution, local dynamics, air-sea interactions and ecosystem assessments. For instance, the interaction of Agulhas rings and filaments can have crucial implications for cross-shelf exchanges and therefore productivity as water exported offshore is generally rich in nutrients and biota, due to the upwelling regime and the shelf edge jet transporting eggs and larvae alongshore. On large scales, the Cape Basin circulation influences the AMOC and climate. The need of observations in the subtropical South Atlantic at these different scales led to the establishment of the South Atlantic MOC (SAMOC) international initiative to enhance further observing systems in this area (Garzoli and Matano, 2011). As part of the SAMOC initiative, several efforts to document the inflows of the two main paths of the upper limb of the AMOC have been undertaken across the Drake Passage (e.g., Chereskin et al., 2009; Chidichimo et al., 2014; Donohue et al., 2016) and south of South Africa (e.g., GoodHope line: Ansorge et al., 2005; Speich et al. 2007; Gladyshev et al., 2008; Swart et al., 2008; Hutchinson et al., 2016). A trans-basin AMOC array, South Atlantic MOC Basin-wide Array (SAMBA), which began as a pilot array in 2008-2009 (Speich et al., 2010; Meinen et al., 2013), continues to grow along $34.5^{\circ} \mathrm{S}$, a crucial latitude to evaluate the MOC variability and the impact of inter-ocean exchanges (Perez et al., 2011; Schiermeier, 2013). SAMBA is a collaboration between Argentina, Brazil, France, South Africa and the United States, with moorings located on the western and eastern boundaries (Speich et al., 2010; Meinen et al., 2013, 2018; Ansorge et al., 2014). Since the pilot deployment described in Meinen et al. (2013), the number of moorings on the boundaries has increased dramatically. The transport and water mass anomalies associated with the deep current and migrating eddies near the western boundary have been well studied (e.g., Meinen et al., 2012, 2017; Valla et al., 2018), but the eastern boundary anomalies have not yet been examined along $34.5^{\circ} \mathrm{S}$.

In the framework of the SAMOC international project and national programmes (SANAP - South African National Antarctic Programme), our work focuses on the eastern part of the SAMBA array (hereafter SAMBA-east) offering an ideal position to observe and characterize mesoscale dynamics - a key link between Indian and Atlantic water exchanges (Fig. 1). The analysis of the SAMBA-east moored data sets, from September 2014 to December 2015, provides evidence of mesoscale features passing through the Cape Basin. Experimental evidence of advected mesoscale eddies through moored arrays along a constant line of latitude or longitude in various parts of the ocean have been presented (Ursella et al., 2011; Sutherland et al., 2011; de Jong et al., 2014) and used to estimate eddy parameters such as their strengths and sizes (Lilly and Rhines, 2002). The main focus of this study is to characterize such mesoscale structures in the Cape Basin region from different data sets obtained along the SAMBAeast array using the Lilly and Rhines (2002) technique and to quantify their impact on local water mass distributions.

\section{Data and methods}

The eastern part of the SAMBA array during September 2014 to December 2015, consisted of four full-depth current meter moorings (hereafter full-depth moorings), eight Current and Pressure recording Inverted Echo Sounder (CPIES), and two bottom mounted acoustic Doppler current profiler (ADCP) moorings that were deployed from the shelf to near the Walvis Ridge offshore along $34.5^{\circ} \mathrm{S}$ (Fig. 1). In this study, we will focus (1) on the four full-depth moorings (hereafter named M1, M2, M3 and M4) extending from the continental shelf edge, at $1121 \mathrm{~m}$ of depth, to $15^{\circ} \mathrm{E}$, at $4474 \mathrm{~m}$ of depth, deployed in September 2014 by the Department of Environmental Affairs (DEA) and the University of Cape Town (UCT), South Africa, from the R/V Algoa and (2) on the four CPIES nearest to the full-depth moorings (hereafter named P1, P2, P3 and P4), deployed in September 2013 by IFREMER, France, and DEA, South Africa, from the R/V SA Agulhas II (Fig. 1, Table 1).

The characteristics of the moorings and CPIES used in this study are summarized in Table 1. All full-depth moorings (M1-M4) have an upward-looking $75 \mathrm{kHz}$ RD Instruments ADCP, deployed at the uppermost float at about 400 $500 \mathrm{~m}$ of depth, set to sample the upper water column at hourly intervals. At selected depths along the mooring lines, SBE 37 MicroCATs, high-accuracy conductivity and temperature recorders, were deployed. Some of these instruments also have pressure recorders and optical oxygen sensors. The oxygen sensors will not be used in this study. All of the full-depth mooring instruments (ADCP and SBE MicroCATs) were still recording on recovery, with the exception of two SBE37 MicroCATs that stopped recording in November 2014 due to low battery power. These two units were both from M4, at depths of 1340 and $3985 \mathrm{~m}$. The sampling period for the full-depth mooring instruments was $1 \mathrm{~h}$. The collected data were tidally filtered using a secondorder Butterworth filter with a 3-day cutoff period. CPIES recorded hourly measurements of round-trip acoustic travel 
Table 1. Moorings and CPIES characteristics. The date format is $\mathrm{dd} / \mathrm{mm} / \mathrm{yyyy}$. The bold values represent the depth of the instruments with pressure recorders.

\begin{tabular}{|c|c|c|c|c|}
\hline & Mooring 1 - M1 & Mooring $2-\mathrm{M} 2$ & Mooring 3 - M3 & Mooring 4-M4 \\
\hline Latitude & $34^{\circ} 23.636^{\prime} \mathrm{S}$ & $34^{\circ} 29.960^{\prime} \mathrm{S}$ & $34^{\circ} 30.010^{\prime} \mathrm{S}$ & $34^{\circ} 30.360^{\prime} \mathrm{S}$ \\
\hline Longitude & $17^{\circ} 35.664^{\prime} \mathrm{E}$ & $17^{\circ} 18.064^{\prime} \mathrm{E}$ & $17^{\circ} 8.3640^{\prime} \mathrm{E}$ & $14^{\circ} 58.810^{\prime} \mathrm{E}$ \\
\hline Water depth (m) & 1121 & 2094 & 2970 & 4474 \\
\hline Start & 17/09/2014 08:00 & 17/09/2014 11:00 & 17/09/2014 16:00 & 19/09/2014 23:00 \\
\hline End & 01/12/2015 05:00 & 01/12/2015 13:00 & 02/12/2015 10:00 & 03/12/2015 05:00 \\
\hline $\mathrm{ADCP}$ & 75 kHZ RDI ADCP & $75 \mathrm{kHZ}$ RDI ADCP & 75 kHZ RDI ADCP & 75 kHZ RDI ADCP \\
\hline Depth (m) & 600 & 605 & 435 & 450 \\
\hline Cell size (m) & 16 & 16 & 16 & 16 \\
\hline Number bins & 34 & 34 & 24 & 24 \\
\hline Depth 1st bin (m) & 582.85 & 588.65 & 410.95 & 413.78 \\
\hline Number of records & 10558 & 10566 & 10587 & 10606 \\
\hline \multirow[t]{2}{*}{$\begin{array}{l}\text { Depth (m) SBE } 37 \text { SMP } \\
\text { MicroCATs C-T }(\mathbf{P}) \\
\text { Recorder }\end{array}$} & $\mathbf{6 0 0}, 770, \mathbf{9 3 0}, 1090$ & $\begin{array}{r}\mathbf{6 0 5}, 810,1020,1230, \\
1435,1642,1850,2070 \\
2070\end{array}$ & $\begin{array}{r}435,730,1030,1325 \\
1620,1720,1915 \\
2210,2505,2880\end{array}$ & $\begin{array}{r}\text { 450, } 895,1340,1780 \\
2250,2665,3110 \\
3550,3985,4360\end{array}$ \\
\hline & CPIES 1 - P1 & CPIES 2 - P2 & CPIES 3 - P3 & CPIES $4-\mathrm{P} 4$ \\
\hline Latitude & $34^{\circ} 24.348^{\prime} \mathrm{S}$ & $34^{\circ} 29.813^{\prime} \mathrm{S}$ & $34^{\circ} 29.964^{\prime} \mathrm{S}$ & $34^{\circ} 30.252^{\prime} \mathrm{S}$ \\
\hline Longitude & $17^{\circ} 33.456^{\prime} \mathrm{E}$ & $17^{\circ} 18.036^{\prime} \mathrm{E}$ & $17^{\circ} 8.3100^{\prime} \mathrm{E}$ & $15^{\circ} 0.161^{\prime} \mathrm{E}$ \\
\hline Water depth (m) & 1266 & 2129 & 2850 & 4482 \\
\hline Start & 07/09/2013 00:00 & 07/09/2013 00:00 & No data & 07/09/2013 00:00 \\
\hline End & 11/08/2015 00:00 & 11/08/2015 00:00 & No data & 11/08/2015 00:00 \\
\hline
\end{tabular}

time, bottom pressure, and the velocity at $50 \mathrm{~m}$ above the seafloor. All of the CPIES were recovered and redeployed, with the exception of $\mathrm{P} 3$ which was unfortunately lost during the recovery. Typically, the pressure sensor of the CPIES exhibits either a linear or an exponential-plus-linear type of drift (Watts and Kontoyiannis, 1990; Donohue et al., 2010; Meinen et al., 2013). After removing the drift following these traditional methods, the same tidal filter has been applied on the CPIES data. The CPIES moorings records were subsampled to one value per day at midnight UTC. An empirical look-up table for hydrographic property profiles, known as the "gravest empirical mode" (GEM) method (Meinen and Watts, 2000; Watts et al., 2001) was constructed from 2213 conductivity-temperature-depth (CTD) and Argo profiles in the region (Fig. 2a). These two-dimensional look-up tables of temperature and salinity as functions of depth and travel time are shown in Fig. 2b, c. The scatter between the original hydrographic data and the GEM fields (Fig. 2d, e) provides an estimate of the accuracy. Following the new thermodynamic equation of seawater, all temperature and salinity is referenced as conservative temperature $\left({ }^{\circ} \mathrm{C}\right)$ and absolute salinity $\left(S_{\mathrm{A}}\left(\mathrm{g} \mathrm{kg}^{-1}\right)\right)$ (IOC et al., 2010). The temperature and salinity scatter is less than $1.5^{\circ} \mathrm{C}$ and $0.1 \mathrm{~g} \mathrm{~kg}^{-1}$, respectively. In the deep ocean, the scatter around the GEM field is a larger fraction of the observed variability; however, this is because the signals at depth are smaller relative to the noise and not because the scatter around the GEM field itself is significantly larger. The GEM method has been successfully applied in the eastern South Atlantic (Meinen et al., 2013, 2018) and across the Agulhas Current off the southeast coast of South Africa (Beal et al., 2015; Elipot and Beal, 2018). Combining the measured travel time from the CPIES (Table 1) with the GEM look-up tables produces daily full water-column hydrographic profiles. We will primarily look at results from the full-depth moorings (Sect. 3.1-3.3) and secondarily look at the CPIES moorings (Sect. 3.4). The set of records presented hereafter were all tidally filtered as mentioned above.

Following Lilly and Rhines (2002), a set of metrics used to characterize eddies in mooring data were defined. The strength and size of an eddy can be defined by the peak azimuthal velocity $(V)$, the "apparent" radius or half-width of the eddy chord passing by a mooring $(X)$, the temporal center of the eddy $\left(t_{0}\right)$, and the eddy's time influence on the mooring $(\Delta T)$. For an advected eddy, the quantification of $V$ needs a separation of the eddy flow from the mean advection flow (magnitude $U$ and direction $\Theta$ ). The first estimate 

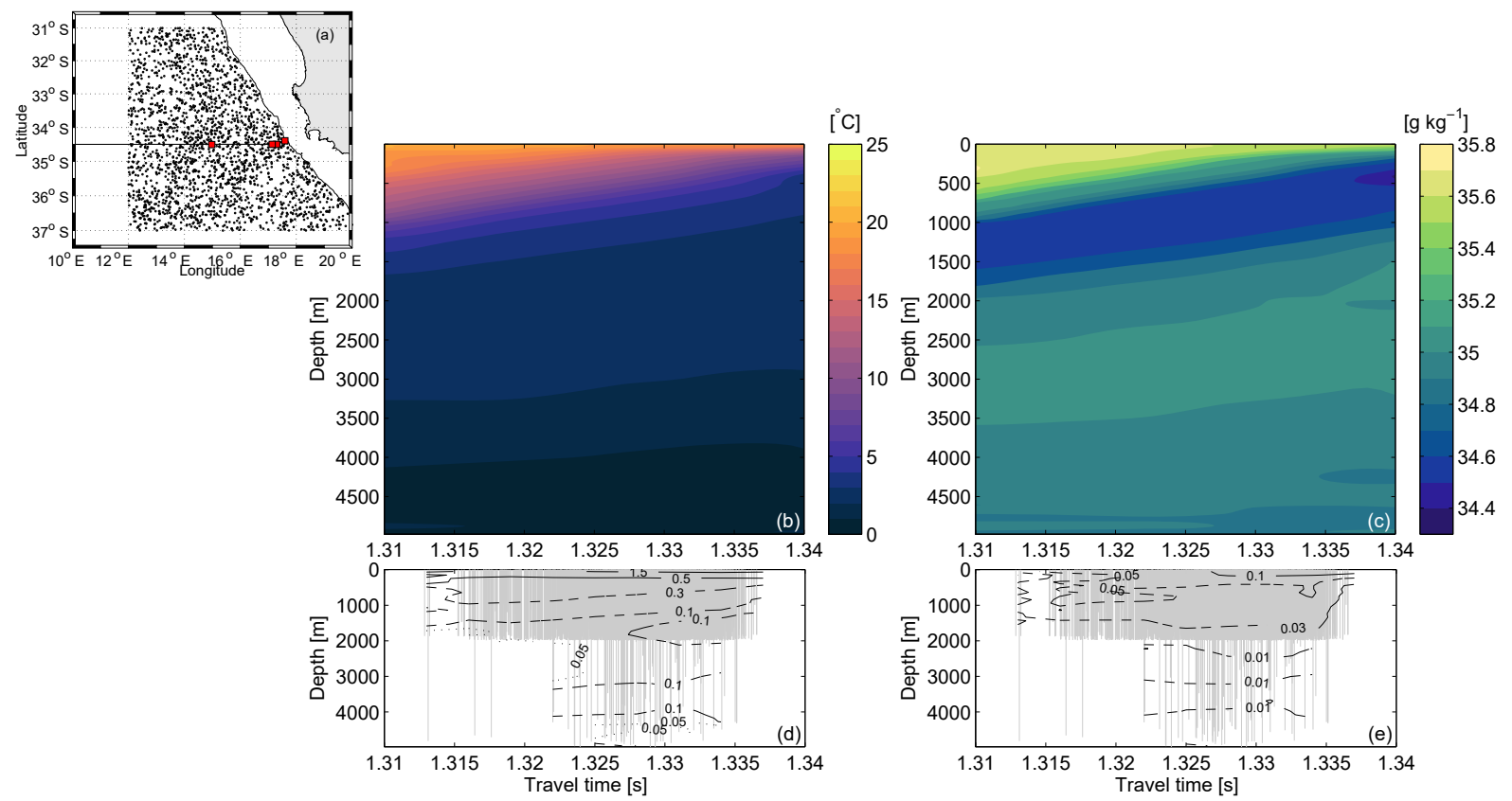

Figure 2. (a) Positions of the CTD and Argo casts from 1983 to 2018 collected around the SAMBA-east transect and used to create the GEM field. The CPIES are identified by the red squares along the transect. Gravest empirical mode (GEM) fields of conservative temperature (b) and absolute salinity (c) determined for the SAMBA-east line. The root-mean-squared (rms) differences between the original hydrographic measurements and the smoothed look-up table values are shown in the lower plots (d, e). The solid, dashed and dotted contours represent progressively smaller contour intervals. The gray vertical lines show the locations of the hydrographic measurements.

of $V$ (hereafter $V_{\mathrm{n}}$ ) is made maximizing the velocity difference over a time window encompassing the eddy and giving initial guesses for $t_{0}$ and $\Delta T$. The mean advection flow direction $\Theta$ is then estimated as it is expected to be perpendicular to the direction of $V_{\mathrm{n}}$. A second measure of $V$ (hereafter $V_{\mathrm{U}}$ ) can be obtained by subtracting an estimate of the advecting flow. For this, two methods exist: the "angle" $\left(U_{\mathrm{a}}\right.$ and $\left.\Theta_{\mathrm{a}}\right)$ and the "filtering" $\left(U_{\mathrm{f}}\right.$ and $\left.\Theta_{\mathrm{f}}\right)$ techniques. The first method minimizes the angle difference between the observed eddy currents and the observed vertical shear. The second method is useful when the advection flow is large compared to the eddy and estimates $U_{\mathrm{f}}$ and $\Theta_{\mathrm{f}}$ by low-pass-filtered velocity time series at the eddy center $t_{0}$ using a Hanning window whose length is 3 times the eddy duration $\Delta T$. More details about these methods can be found in Lilly and Rhines (2002) and the Appendix C of Lilly et al. (2003). For the purpose of this study, the duration of the eddy $(\Delta T)$ and the magnitude of the advection flow $\left(U_{\mathrm{a}}\right.$ and $\left.U_{\mathrm{f}}\right)$ are used to estimate the apparent radius of the eddy: $X=\Delta T \times U$. Finally, the Rossby number can be assessed as $(2 \times|V|) /(X \times f)$. In a purely linear flow, the Rossby number is equal to zero and implies that the momentum equation is dominated by the geostrophic balance between the pressure gradient force and the Coriolis acceleration.

Hydrographic sampling has been conducted along the eastern section of the SAMBA transect during five cruises on board the R/V SA Agulhas II (September 2013, Septem- ber 2014 and July 2015) and the R/V Algoa (September 2014, and December 2015). During each cruise, CTD casts were carried out at several stations along the transect using multiple SeaBird Electronics SBE 911+ CTD systems and sensors, in order to measure temperature and conductivity. Conductivity was used to derive salinity and then, combined with temperature, to determine density. CTDs were conducted from the surface to within $5-10 \mathrm{~m}$ of the seafloor on the R/V SA Agulhas II, with generally five casts offshore $\left(0-15^{\circ} \mathrm{E}\right)$ and five casts over the continental slope (15$17^{\circ} 35^{\prime} \mathrm{E}$ ). CTDs on the R/V Algoa were conducted to a maximum depth of $1000 \mathrm{~m}$, with eight casts over the continental slope $\left(15-17^{\circ} 35^{\prime} \mathrm{E}\right)$ and a zonal resolution of $0.3-0.5^{\circ}$. Discrete seawater samples were collected at selected depths for the analysis of salinity with a Guildline Portsal salinometer (van den Berg, 2015) and used after the cruise to calibrate the CTD conductivity sensors. Following the procedure of Kanzow et al. (2006), the SBE MicroCat's sensors were attached to the rosette and data were recorded simultaneously between the surface and $1000 \mathrm{~m}$ depth due to the limitation of the vessel. As the CTD sensors on the R/V Algoa had not been recently calibrated by the manufacturer and the surface mixed layer did not provide a stable environment to assess the differences, the correction coefficients applied to the MicroCat's data can introduce additional bias. To assess the accuracy of these measurements, we compared the MicroCat's data with World Ocean Atlas (WOA) 2013 climatology pro- 
files (Locarnini et al., 2013; Zweng et al., 2013). We compared the mean value of temperature and absolute salinity in the MicroCat's records and the climatology profiles below $2000 \mathrm{~m}$ to avoid depth-dependent offsets to the comparison due to strong vertical gradients in the thermocline. The mean differences of $0.14{ }^{\circ} \mathrm{C}$ for the temperature and $-0.01 \mathrm{~g} \mathrm{~kg}^{-1}$ for the absolute salinity were estimated between WOA and the MicroCATs below $2000 \mathrm{~m}$. There differences are large 1 or 2 orders of magnitude larger than the instrument accuracies - but they provide an upper bound for the biases in the MicroCat's data in lieu of calibrated CTD sensors. In any case, these mean differences are small compared with the robust signals analyzed in this study.

Satellite imagery was analyzed to give an overview of the surface dynamics in the Cape Basin region. Sea surface temperature (SST) was derived from ODYSSEA, a Group for High Resolution Sea Surface Temperature (GHRSST) regional product interpolated on a $0.02^{\circ}$ grid for the South African area. The sea surface height (SSH) and geostrophic velocity fields are derived from the Delayed Time Maps of Absolute Dynamic Topography (MADT) mapped daily on a $1 / 4^{\circ}$ Mercator grid (Pujol et al., 2016). An eddy detection method based on the algorithm developed by Chaigneau et al. $(2008,2009)$ was applied to these absolute dynamic topography (ADT) fields. This new method detects local ADT extrema to identify potential eddy centers. For each potential eddy centers, the algorithm looks for closed ADT contour lines with an increment of plus or minus $1 \mathrm{~mm}$ (e.g., Chaigneau et al., 2011). This $1 \mathrm{~mm}$ threshold step is a bit smaller than the typical value used in the literature; however, recent work has shown that it leads to more accurate eddy sizes and amplitudes (Faghmous et al., 2015). This criterion prevents the misidentification of large eddies as two smaller ones (Chaigneau et al., 2008, 2009). The spatially largest closed ADT contour line encompassing one extremum corresponds to the eddy edge. Following the filtering criteria of Faghmous et al. (2015) for regional study, we only consider eddies with a minimum lifetime of 7 days. The method provides the radius $\left(R_{\text {out }}\right)$ and the amplitude of the eddies associated with the outermost contour of ADT. In addition, the eddy ADT contour along which the norm of the azimuthal geostrophic velocity is the highest $\left(V_{\max }\right)$ is calculated to provide the radius of the coherent core of the eddy $\left(R_{V}\right.$; e.g., Nencioli et al., 2010; Chelton et al., 2011). We validated our results with the well-known Mesoscale Eddy Trajectory Atlas (META) product based on an eddy-tracking methodology developed by Chelton et al. (2011). The main difference between the META eddy tracking and our methodology is the use of an improved eddy-tracking method which takes into account both merging and splitting events. In both products, the method is based on the low displacement of eddies compared to their size. Each eddy was tracked within the boundary of the eddy defined at the previous time step following the method of Pegliasco et al. (2015). In our version, no cost function was applied to the eddies in cases of multiple as- sociation, but a minimum of overlapping surfaces is added. Consequently, splitting events are identified when one eddy is associated with two or more eddies the next day as well as merging events in the reverse case. The eddies that are discussed in the present paper are all identifiable by both the new method and by the META product. In this study, the eddy statistics are based on our method because it better tracks splitting/merging of eddies, and we only show the META results to validate the new methodology.

\section{Results}

\subsection{Upper-ocean properties and dynamics}

To characterize the hydrodynamical properties of the mesoscale features passing through the SAMBA-east array, the measurements of the upward-looking ADCP are analyzed together with concurrent altimetry data. From September 2014 to December 2015, the mean and the standard deviation of the near surface velocities recorded at the shallowest depth (between 40 and $60 \mathrm{~m}$ depth) by the upwardlooking ADCP is between $24.6 \pm 11.4 \mathrm{~cm} \mathrm{~s}^{-1}$ at the mooring nearest to the shelf (M1 - thin blue line; Fig. 3a, b) and $29.9 \pm 22.0 \mathrm{~cm} \mathrm{~s}^{-1}$ at the offshore mooring (M4 - thin red line; Fig. 3g, h). Typically, the shallowest depth sampled was near the surface but below the Ekman layer (mean value of about $36 \mathrm{~m}$ along the section) allowing a comparison with the surface geostrophic velocity derived from satellite altimetry. Statistical comparisons between ADCP near-surface velocities and the surface geostrophic velocity derived from satellite altimetry have been made (Table 2, Fig. 3). The comparison has been undertaken mostly in terms of correlation and rms differences between the zonal and meridional components of M1-M4 ADCPs $\left(u_{m}, v_{m}\right)$ and those from altimetry at the nearest gridded location $\left(u_{\mathrm{alti}}, v_{\mathrm{alti}}\right)$ :

$\Delta V_{\mathrm{rms}}=\left[\frac{1}{N} \sum\left[\left(V_{m}-\overline{V_{m}}\right)-\left(V_{\text {alti }}-\overline{V_{\text {alti }}}\right)\right]^{2}\right]^{1 / 2}$,

with $V$ the zonal or the meridional components of the velocity and $m$ the index of the mooring. Additionally, comparisons were made by computing the bias (Eq. 2).

bias $=\overline{V_{m}}-\overline{V_{\text {alti }}}$

Correlations between ADCP and altimetry velocity estimates $(R)$ are significant and fell in the range 0.29-0.83 (Table 2). To determine the significance of the correlations, the number of independent samples, also known as the number of degrees of freedom (Thomson and Emery, 2014), is estimated by dividing the record length by twice the integral timescale calculated from the variability in each respective quantity ( $\sim 40-50$ days). The integral timescale is estimated from the integral of the autocorrelation function to its first zero crossing (see Appendix B in Meinen et al., 2009 for more information). $\Delta V_{\mathrm{rms}}$ varied from 12.9 to $15.9 \mathrm{~cm} \mathrm{~s}^{-1}$ 


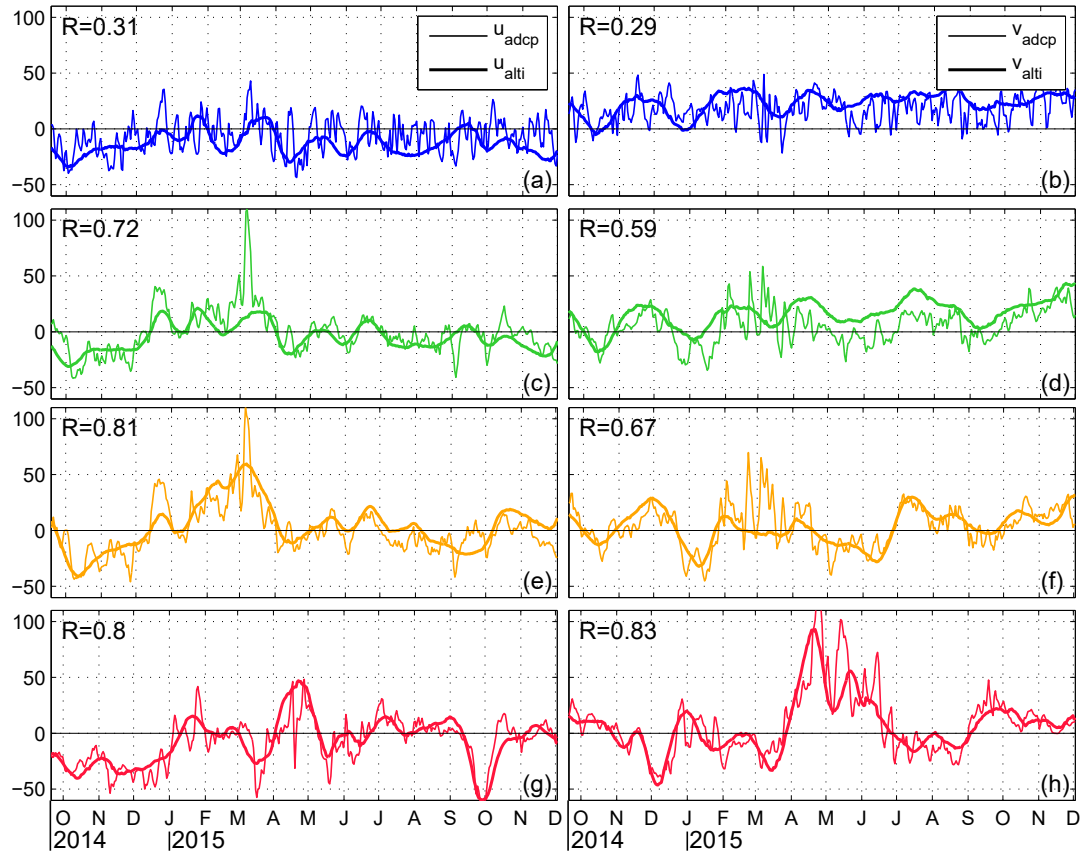

Figure 3. Temporal evolution of the near-surface velocities recorded at the last bin by the upward-looking ADCP (thin lines) and the surface geostrophic velocity derived from satellite altimetry (bold lines). The $u$ (left column) and $v$ (right column) component of the current velocities $\left(\mathrm{cm} \mathrm{s}^{-1}\right)$ are represented at M1 (a, b - blue line), M2 (c, d - green line), M3 (e, f - yellow line) and M4 (g, h - red line). The correlation coefficient value $(R)$ is indicated in the top left corner of each panel.

(Table 2). The absolute values of the biases were typically between 1 and $6 \mathrm{~cm} \mathrm{~s}^{-1}$, with a maximum of $8.8 \mathrm{~cm} \mathrm{~s}^{-1}$ at $\mathrm{M} 2$. Correlation between the $u$-component of these velocity measurements showed values greater than 0.7 for the three offshore moorings. Weak correlation coefficients for both components were observed for the mooring closest to the shore (M1, $1121 \mathrm{~m}$ of depth). The coefficient for the $v$ component gradually increases across the continental slope, moving away from the shelf. The correlations for sites away from the shelf are significant considering the mean zonal correlation scales of the satellite product of $150 \mathrm{~km}$ at that latitude $(\mathrm{Pu}-$ jol et al., 2016). The poor correlation for both velocity components at M1 can be mainly attributed to its position too close to the coast ( $\sim 160 \mathrm{~km}$ off shore, at the shelf break), and it is therefore embedded in a different dynamical regime than purely geostrophic. The comparisons reveal that satellite data provide a reasonable description of the upper-ocean circulation (between 40 and $60 \mathrm{~m}$ depth) across the continental slope along our mooring arrays, except near the shelf break (i.e., well inshore of the $1200 \mathrm{~m}$ isobath).

In light of these results, the dynamics inferred from satellite altimetry can provide a basis for understanding the variability in the zonal and meridional components of the upper-layer velocity between 40 and $60 \mathrm{~m}$ depth for the offshore moorings (M2 to M4). Using the new eddy detection technique, we can first estimate statistical characteristics of mesoscale eddies passing through the mooring line during
Table 2. Summary of comparison statistics for satellite altimetry and moored current meter, with $R$ (the correlation coefficient), $\Delta V_{\text {rms }}$ (the root mean square differences between the zonal and meridional components of ADCPs and those from altimetry (Eq. 1)) and the bias between those components (Eq. 2).

\begin{tabular}{|c|c|c|c|c|c|c|}
\hline & \multicolumn{2}{|c|}{$R$} & \multicolumn{2}{|c|}{$\begin{array}{c}\Delta V_{\mathrm{rms}} \\
\left(\mathrm{cm} \mathrm{s}^{-1}\right)\end{array}$} & \multicolumn{2}{|c|}{$\begin{array}{c}\text { Bias } \\
\left(\mathrm{cm} \mathrm{s}^{-1}\right)\end{array}$} \\
\hline & $u$ & $v$ & $u$ & $v$ & $u$ & $v$ \\
\hline $\begin{array}{l}\text { M1 } \\
(54.9 \mathrm{~m})\end{array}$ & 0.31 & 0.29 & 15.4 & 13.3 & 5.3 & -1.5 \\
\hline $\begin{array}{l}\text { M2 } \\
(60.7 \mathrm{~m})\end{array}$ & 0.72 & 0.59 & 14.0 & 12.9 & 3.0 & -8.8 \\
\hline $\begin{array}{l}\text { M3 } \\
(43.0 \mathrm{~m})\end{array}$ & 0.81 & 0.67 & 13.3 & 13.9 & -5.8 & 1.2 \\
\hline $\begin{array}{l}\text { M4 } \\
(45.8 \mathrm{~m})\end{array}$ & 0.80 & 0.83 & 13.0 & 15.9 & -4.3 & -4.9 \\
\hline
\end{tabular}

the measurement period of the full-depth moorings along $34.5^{\circ} \mathrm{S}$ (September 2014 to December 2015). A total number of 16 Agulhas rings, defined as anticyclones that enter the Cape Basin crossing the C-line (Fig. 1), were detected and confirmed by the META product. This line extends from the southernmost tip of Africa (Cape Agulhas) and, after crossing various seamounts, ends at $45^{\circ} \mathrm{S}$ in the Southern Ocean. From our altimetric tracking, the median radius and standard deviation of these features are equal to $85 \pm 43 \mathrm{~km}$ for $R_{\text {out }}$ 


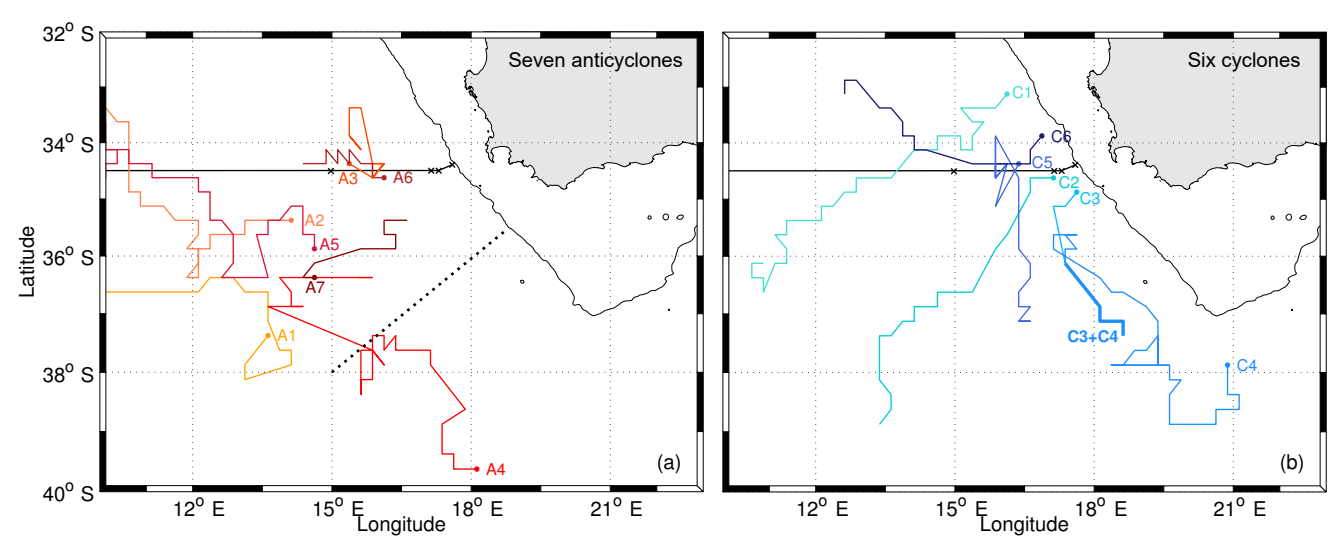

Figure 4. Eddy trajectories from 15 September 2014 to 15 December 2015 for eddies influencing the mooring measurements. The eddies are named A1-A7 (anticyclonic eddies - a) and C1-C6 (cyclonic eddies - b), with the numbers assigned in chronological order by the eddy-tracking scheme. The circles indicate the starting positions of an eddy track. The bold blue line in (b) represents the trajectory of an eddy after a merging. (a) The dashed black line represents the northern route of Agulhas rings defined by Dencause et al. (2010).

Table 3. Characteristics of the eddies passing over the moorings from satellite altimetry. The time period, the radius, and the azimuthal velocity of the different eddies are derived from our eddy detection method. The eddies are named C1-C6 (cyclonic eddies) and A1-A7 (anticyclonic eddies), with the numbers assigned in chronological order by the eddy-tracking scheme.

\begin{tabular}{lrrrrrrr}
\hline$\Delta t$ (days) & $\mathrm{C} 1$ & $\mathrm{C} 2$ & $\mathrm{C} 3$ & $\mathrm{C} 4^{*}$ & $\mathrm{C} 5$ & $\mathrm{C} 6$ & \\
$R_{V}(\mathrm{~km})$ & & & & & & & \\
$V_{\max }\left(\mathrm{cm} \mathrm{s}^{-1}\right)$ & & & & & & & \\
\hline $\mathrm{M} 2, \mathrm{M} 3$ & & $28-37$ & 20 & $27-28$ & $55-71$ & $11-17$ & \\
& & $35-36$ & 36 & 76 & $61-65$ & $48-56$ & \\
& & -36.0 & -38 & -66 & -41 & -26 & \\
\hline M4 & 93 & & & & 61 & 26 & \\
& 62 & & & & 65 & 68 & \\
& -34 & & & & -43 & 68 & \\
\hline$\Delta t$ (days) & $\mathrm{A} 1$ & $\mathrm{~A} 2$ & $\mathrm{~A} 3$ & $\mathrm{~A} 4^{*}$ & $\mathrm{~A} 5$ & $\mathrm{~A} 6$ & $\mathrm{~A} 7$ \\
$R_{V}(\mathrm{~km})$ & & & & & & & \\
$V_{\max }\left(\mathrm{cm} \mathrm{s}{ }^{-1}\right)$ & & & & & & & \\
\hline M4 & 19 & 34 & 2 & 17 & 56 & 2 & 28 \\
& 104 & 80 & 92 & 110 & 154 & 44 & 77 \\
& 54 & 33 & 21 & 59 & 37 & 32 & 51 \\
\hline
\end{tabular}

* Eddies generated at the Agulhas retroflection.

and $66 \pm 38 \mathrm{~km}$ for $R_{V}$. The azimuthal speed of these Agulhas rings $\left(V_{\max }\right)$ is equal to $0.49 \pm 0.24 \mathrm{~m} \mathrm{~s}^{-1}$ with a translation speed, mainly northwestward of $11 \pm 6 \mathrm{~km} \mathrm{day}^{-1}$. Considering our observing system along the SAMBA-east line, seven anticyclonic and six cyclonic eddies influenced the mooring measurements during the $\sim 14$-month period of recording at sites M2 (P2) to M4 (P4) (Fig. 4, Table 3). All these mesoscale features passed over one of the moorings considering their outermost contours of ADT and have a closed contour in the satellite dynamic-height amplitude of at least $1 \mathrm{~cm}$. Two of these eddies (anticyclonic A4 and cyclonic C4) were generated at the Agulhas retroflection and propagated into the Cape Basin through the northern route defined by
Dencausse et al. (2010) (dashed black line - Fig. 4a). These two eddies have the largest azimuthal speed $\left(V_{\max }\right)$ compared with other eddies detected in the area (Table 3). Four of the anticyclonic eddies (A1, A2, A5 and A7) observed in this study are generated by the splitting of an Agulhas ring and two are generated north of the SAMBA line (A3 and A6). Cyclonic eddy $\mathrm{C} 5$ is generated by the splitting of $\mathrm{C} 4$ and the other four cyclonic eddies are generated over the slope off the Cape Peninsula.

The currents measured during September 2014-December 2015 in the top $500 \mathrm{~m}$ of the water column contain a number of sudden rotational events, seen in the time series of the current vector stick plot (Fig. 5). These transitions in the velocity 


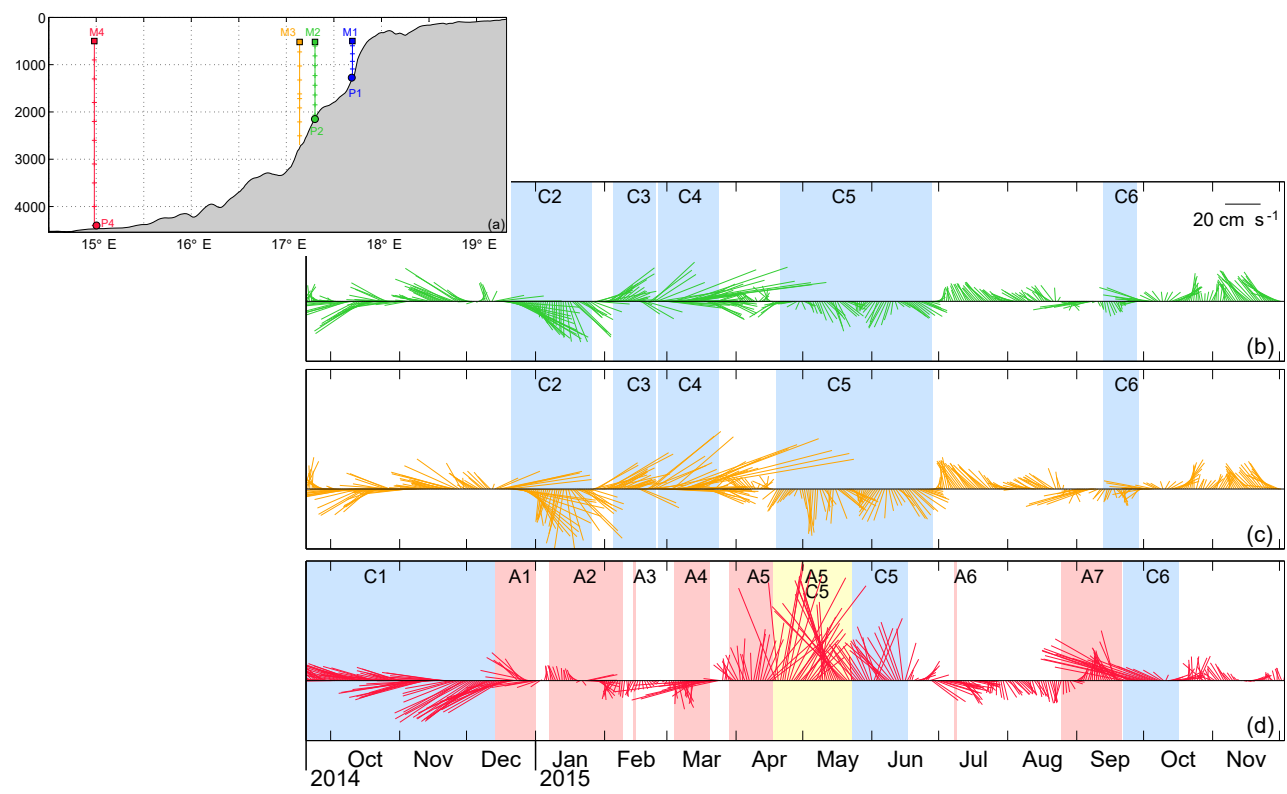

Figure 5. (a) Vertical scheme of the mooring lines positions along the latitude $34.5^{\circ} \mathrm{S}$. The squares represent the upward-looking ADCP positions, the small horizontal lines indicate the SBE MicroCAT's sensors and the circles at the bottom show the CPIES. Temporal evolution of the current vector stick plot at M2 (b), M3 (c) and M4 (d). One vector per day is shown. The shaded areas show the eddy events defined with altimetry data (red: anticyclonic eddies; yellow: dipole event; blue: cyclonic eddies).

field are associated with mesoscale eddies passing through the mooring line. The altimetry data allow us to examine the impact of six cyclonic (blue shaded areas - Fig. 5) and seven anticyclonic eddies (red shaded areas - Fig. 5) on zonal and meridional velocity at the three mooring sites. Moreover, the data records show that the presence of one dipole (counterrotating eddies) affects the velocity measurements (yellow shaded area - Fig. 5). The presence of this dipole is confirmed in the ODYSSEA SST field by its mushroom-like pattern, the typical surface signature of these features.

To have more of a consistent and complete picture of the mesoscale dynamics in the Cape Basin, the position of these eddies observed by satellite altimetry were analyzed in relation to variations in the ODYSSEA SST field (Fig. 6). On 1 December 2014, both eddy identification methods detect one cyclonic eddy (C1) and one anticyclonic eddy (A1) close enough to the mooring line to affect the measurements (Fig. 6a). Approximately 1 month later (Fig. 6b), C1 and A1 move westward. At that time, a new cyclonic eddy (C2) is generated on the slope, at the South Benguela upwelling front, and a new anticyclonic eddy (A2) is generated by the splitting of A1.

On 20 February 2015 (Fig. 6c), an anticyclonic eddy (A3) is present between M3 and M4 and a new cyclonic eddy (C3) is generated at $35^{\circ} \mathrm{S}$. This cyclonic eddy merges afterwards with an intense cyclonic eddy (C4) coming from the Agulhas retroflection. After the merging, the cyclonic eddies $\mathrm{C} 3$ and C4 (called C4) affect the measurements of M2-M3 until the end of March (Fig. 5c, d). This strong northeastward cur- rent is also intensified by an intense cross-shelf density front that is enhanced at that time due to an upwelling event and the northward migration of an Agulhas ring A4 (Fig. 6d). On 21 March 2015, A4 splits to generate A5. This anticyclonic eddy was close enough to M4 to induce the northward propagation of a warm filament on 9 April 2015 (Fig. 6e).

At the end of April, an intense dipole is observed due to the interaction of eddies A5 and C5. Note that cyclonic eddy $\mathrm{C} 5$ is generated by the splitting of $\mathrm{C} 4$ on 18 April 2015. The dipole (A5, C5) induces a strong northward current that injected cold surface water across the mooring array on 25 April (Fig. 6f) and warmer Agulhas Current water during the month of May (Fig. 6g).

After this intense event, the satellite imagery still reveals the presence of cyclonic eddy $\mathrm{C} 5$ and a new anticylonic eddy (A6) in July between M3 and M4 (Fig. 6h). On 15 September 2015 (Fig. 6i), the presence of a cyclonic eddy (C6) over the mooring line and an anticyclonic eddy (A7) generate a warm filament propagating toward M4

In summary, the moorings over the slope (M2 and M3) are affected by five cyclonic eddies identified by the two methods of eddy detection (Table 3; Figs. 5 and 6) over the measurement period from September 2014 to December 2015. The largest velocity perturbations over the slope are associated with cyclonic eddy $\mathrm{C} 4$. M4 records show the influence of many anticyclonic eddies and three cyclonic eddies. The largest velocity perturbations are seen at M4 during the presence of the dipole A5 and C5. The presence of several of these mesoscale features induces the propagation of two 

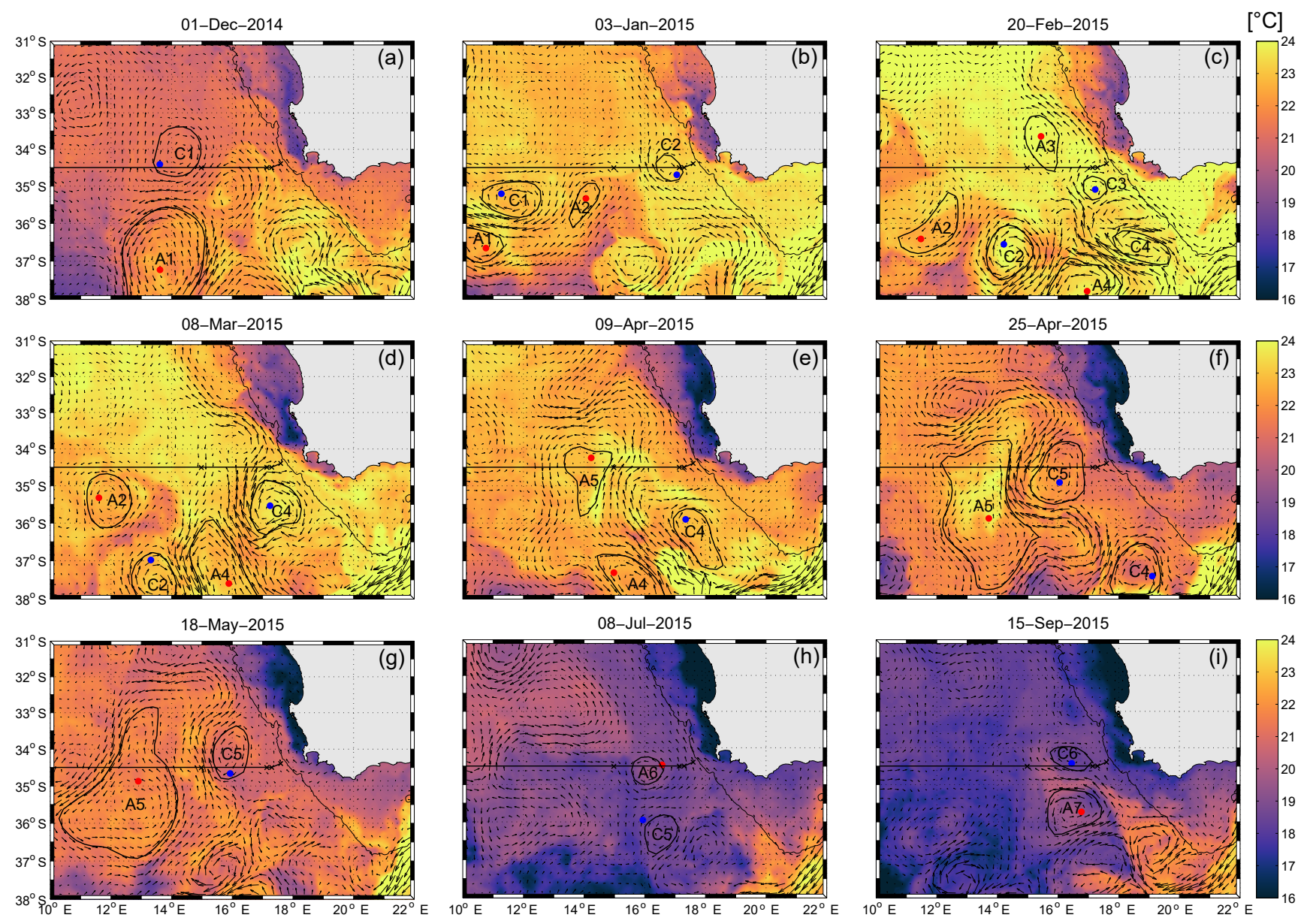

Figure 6. SST satellite images for selected dates between 1 December 2014 to 15 September 2015. The black line denotes the position of the SAMBA line, and the crosses represent the mooring positions. Black contours show the coherent core of the eddies identified by the new method of detection. The colored dots (red for anticyclonic eddy and blue for cyclonic eddy) are the eddy centers detected in the META product.

warm filaments and two injections of relatively colder surface water and relatively warmer Agulhas Current water.

\subsection{Case studies - upper water column}

From the combined analysis of satellite and mooring data in Sect. 3.1, we selected the period between March and June 2015 to analyze eddy-like features, filaments and strong intrusions of cold water or Agulhas Current water due to eddy-eddy interactions. We focus on the variability at M4, which exhibits the strongest variations in responses to passing mesoscale features.

Following the method of Lilly and Rhines (2002), the coherent eddies, dipoles or filaments in mooring data can be detected and assessed in a more quantitative fashion. The zonal and meridional components of the velocity measured at the mooring can be placed on a hodograph plane (Fig. 7a, b, c). In this plane, a combination of a straight line with a segment of a circle (called D-shaped) reflects an eddy struc- ture. The nearer the eddy's center passes to the mooring, the more the hodograph appears as a straight line. An eddy sliced through its exact center or a filament lead to the same type of hodograph (straight line). Eddies can be further distinguished from fronts and filaments using progressive vector diagrams (PVDs) (Fig. 7d, e, f). The eddy structure presents bends, unlike fronts or filaments, which result in straight lines. Concerning the hodographs for a dipole, it is similar to that of an eddy if one of the cores passes over the mooring. If the mooring measures the velocity in between the two cores, the hodograph shows a pulse with a strong increase and decrease in the currents.

In accordance with the Lilly and Rhines (2002) detection method, we have isolated three case studies between March and June 2015. Each case study is associated with one feature which can generate different events. The first case study focused on anticyclonic eddy A4, its splitting which generates A5 and the propagation of a filament along its border. The second case study detailed the dynamics of cyclonic eddy C5, 


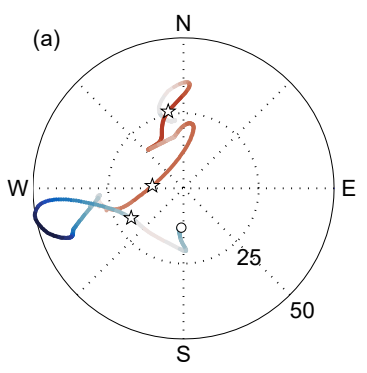

(d)

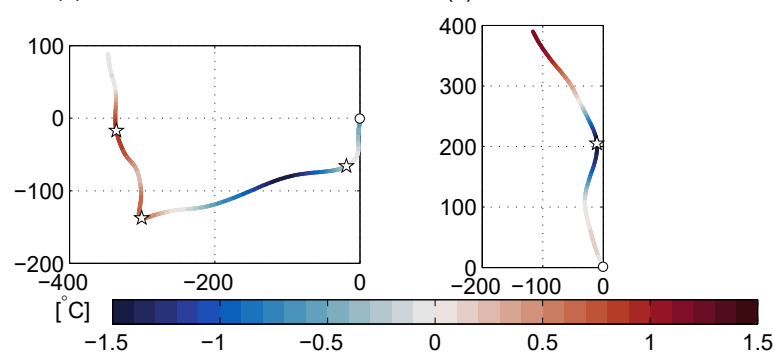

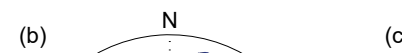
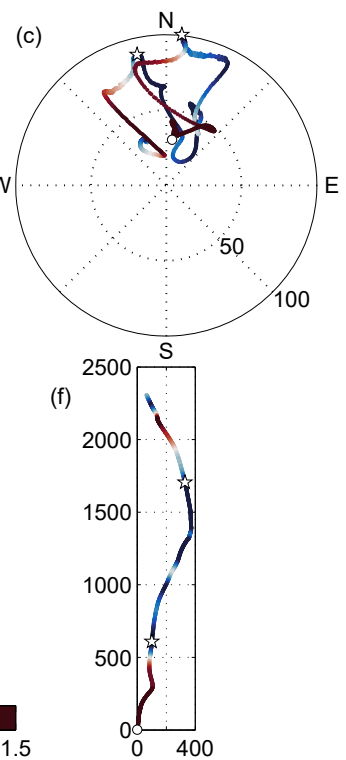

Figure 7. (a, b, c) Hodograph of the mean currents of the upper water column observed at M4 for three case studies (a-anticyclonic eddy; $\mathbf{b}$ - cyclonic eddy; $\mathbf{c}$-dipole). Color represents the temperature recorded at the first SBE37 MicroCATs de-meaned over the time period of each case studies (a: 9 March-6 April 2015; b: 28 May-10 June 2015; c: 8 April-29 May 2015). The estimated centers of six events have been marked with white stars. The beginning of each time series has been marked with white dots. (d, e, f) Progressive vector diagram for the mean currents of the upper water column observed at M4 for three case studies. Color, time period and symbols are the same as the hodograph.

and the third one described the dynamics of a dipole (A5/C5) generating two current pulses.

The first case study between 9 March and 6 April 2015 (Fig. 7a, d) illustrates the presence of anticyclonic eddies A4 and A5. The D-shape structures on the hodograph (Fig. 7a) and the bends to the right associated with anticylonic eddies on the PVD (Fig. 7d) appear clearly. To better illustrate these events, the temperature recorded at the first SBE MicroCATs (depth between 430 and $750 \mathrm{~m}$ ) de-meaned over the time period of each case study is presented. Within the period during which a positive temperature anomaly associated with the anticyclonic eddies appears in the record, the hodograph tends to be relatively straight. At the end of the time period, the impact of a filament propagating northward due to the presence of A5 is observed as a straight line on both planes (Fig. 7a, d). The second hodograph and PVD between 28 May and 10 June 2015 (Fig. 7b, e) display a D-shaped structure and a bend to the left associated with a negative temperature anomaly typical of a cyclonic eddy. According to its time of occurrence, this mesoscale feature corresponds to C5. Finally, the final case study between 8 April and 29 May 2015 (Fig. 7c, f) exhibits very strong currents with two acceleration and deceleration phases that are associated with a dipole.

Following these three identified cases studies, the verticaltemporal structure of eddy-like features and filaments and strong intrusions of cold water or Agulhas Current water due to eddy-eddy interactions are analyzed. Moreover, the estimated sizes and strength of eddies (A4, A5 and C5) can be defined (Table 4) according to the Lilly and Rhines (2002) method detailed in Sect. 2.

The case of anticyclonic eddies. From the middle to the end of March (Fig. 8a, b), M4 is impacted by Agulhas rings A4 and A5. The vertical-temporal section of the $u$ and $v$ component of the current speed (Fig. 8c, d) shows an eddylike structure on 14 and 24 March 2015. The vertical structure of the first Agulhas ring A4 is not evident as it is associated with an advecting flow directed to the southwest $(\Theta-$ Table 4). For the second anticyclonic eddy, A5, the direction of the mean flow shifts toward the west $(\Theta-$ Table 4$)$ and so the eddy-like structure is much clearer in the perpendicular direction ( $v$ component, Fig. 8d). The azimuthal eddy velocities reach $26.0 \mathrm{~cm} \mathrm{~s}^{-1}$ for A4 and $21.7 \mathrm{~cm} \mathrm{~s}^{-1}$ for A5 $\left(V_{\mathrm{U}}-\right.$ Table 4$)$ from the surface to $200-250 \mathrm{~m}$ depth. During this period, an increase in temperature (salinity) of $2.4^{\circ} \mathrm{C}$ $\left(0.35 \mathrm{~g} \mathrm{~kg}^{-1}\right)$ is recorded at the first SBE37 MicroCATs between 430 and $450 \mathrm{~m}$ depth (Fig. 8e). We can also evaluate a downshift of the isopycnal layer by about $200 \mathrm{~m}$ for both eddies (Fig. 8f). This quantity is found by interpolating the potential density within the mean vertical profile derived from CTDs on the R/V SA Agulhas II. At the end of the time period (2 April), the propagation of a warm filament at the eastern side of A5 is identified. The measured $v$ component of the velocity (Fig. 8d) shows at that time a strong northward flow. From the satellite altimetry (colored circles at the top of Fig. 8c, d), the velocity component magnitudes 
Table 4. Estimate eddy parameters. $t_{0}$ : the eddy's center apparent at M4; $\Delta T$ : temporal half eddy duration; $U / \Theta_{\mathrm{a} / \mathrm{f}}\left(X_{\mathrm{a} / \mathrm{f}}\right):$ the estimated mean flow magnitude and direction (eddy apparent radius) using the angle method (subscript "a") or the filtering method (subscript " $\mathrm{f}$ "). $V_{\mathrm{n}} / V_{\mathrm{U}}$ : the estimated maximum eddy currents using the normal (subscript "n") or the U subtraction method (subscript "U"). Rossby number using the different value for $V$ and $X$.

\begin{tabular}{|c|c|c|c|}
\hline & A4 & A5 & $\mathrm{C} 5$ \\
\hline$t_{0}$ & 14 Mar $2015-15: 00$ & $24 \operatorname{Mar} 2015-21: 00$ & 3 June $2015-16: 00$ \\
\hline$\Delta T(\mathrm{~h})$ & 54 & 48 & 25 \\
\hline$U_{\mathrm{a}}\left(\mathrm{cm} \mathrm{s}^{-1}\right)$ & 27.0 & 18.3 & 50.7 \\
\hline$\Theta_{\mathrm{a}}$ & 110 & 77 & 2 \\
\hline$U_{\mathrm{f}}\left(\mathrm{cm} \mathrm{s}^{-1}\right)$ & 28.9 & 16.5 & 49.5 \\
\hline$\Theta_{\mathrm{f}}$ & 150 & 77 & 2 \\
\hline$V_{\mathrm{n}}\left(\mathrm{cm} \mathrm{s}^{-1}\right)$ & 25.8 & 20.6 & -19.2 \\
\hline$V_{\mathrm{U}}\left(\mathrm{cm} \mathrm{s}^{-1}\right)$ & 26.0 & 21.7 & -20.0 \\
\hline$X_{\mathrm{a}}(\mathrm{km})$ & 52.4 & 31.6 & 45.7 \\
\hline$X_{\mathrm{f}}(\mathrm{km})$ & 56.2 & 28.4 & 44.5 \\
\hline Rossby number & $0.11-0.12$ & $0.15-0.17$ & 0.10 \\
\hline
\end{tabular}

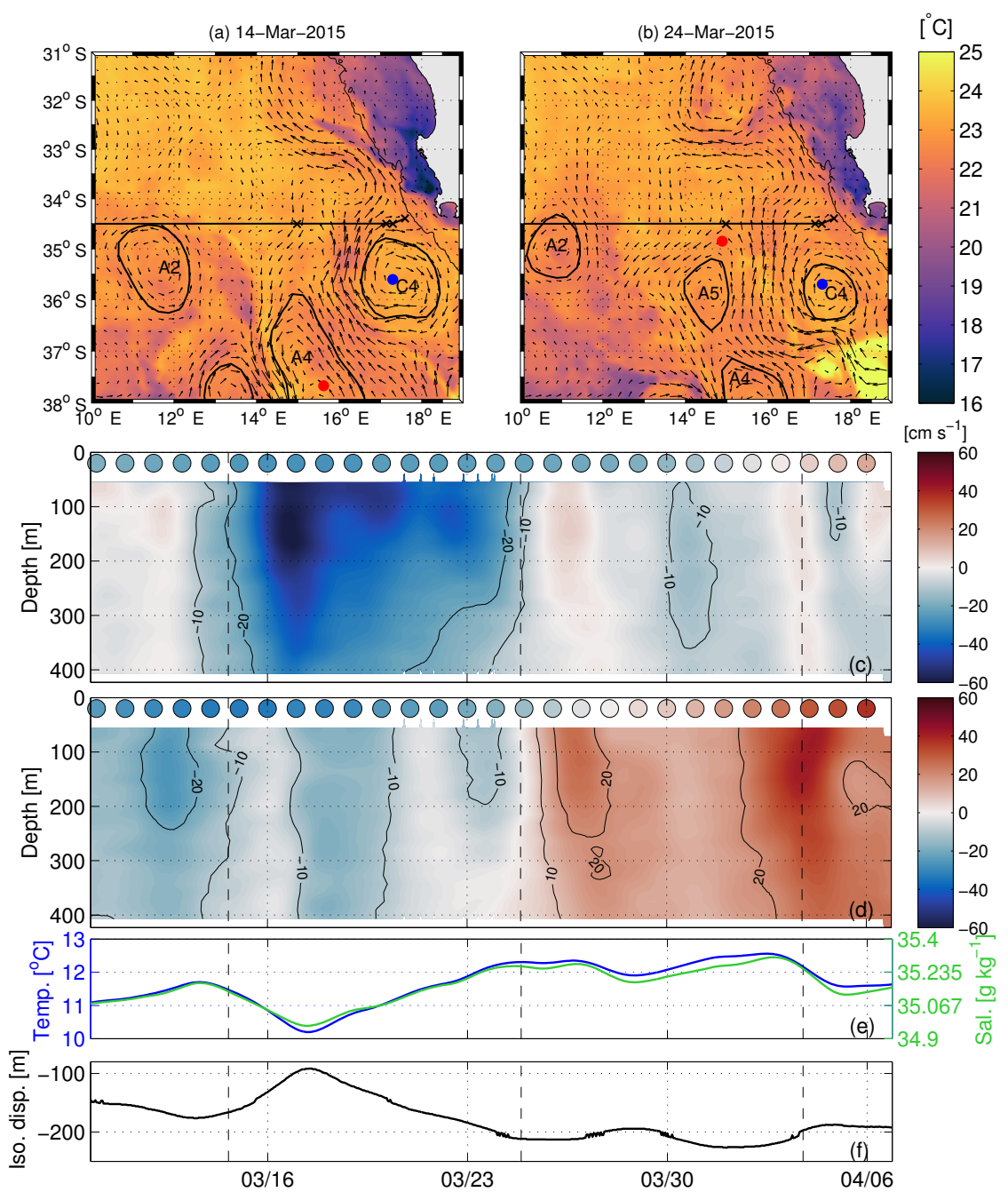

Figure 8. Anticyclonic eddy: (a, b) SST satellite images for selected dates (vertical black lines on the time series). Vertical-temporal section of the $u$ component (c) and $v$ component (d) of the current speed measured from the upward-looking ADCP at M4. The colored circles at the top of the section show the $u$ and $v$ component of the current speed from altimetry data. (e) Temporal evolution of temperature (blue line) and salinity (green line) and (f) the isopycnal displacement recorded at the first SBE37 MicroCATs between 430 and $450 \mathrm{~m}$ depth. 


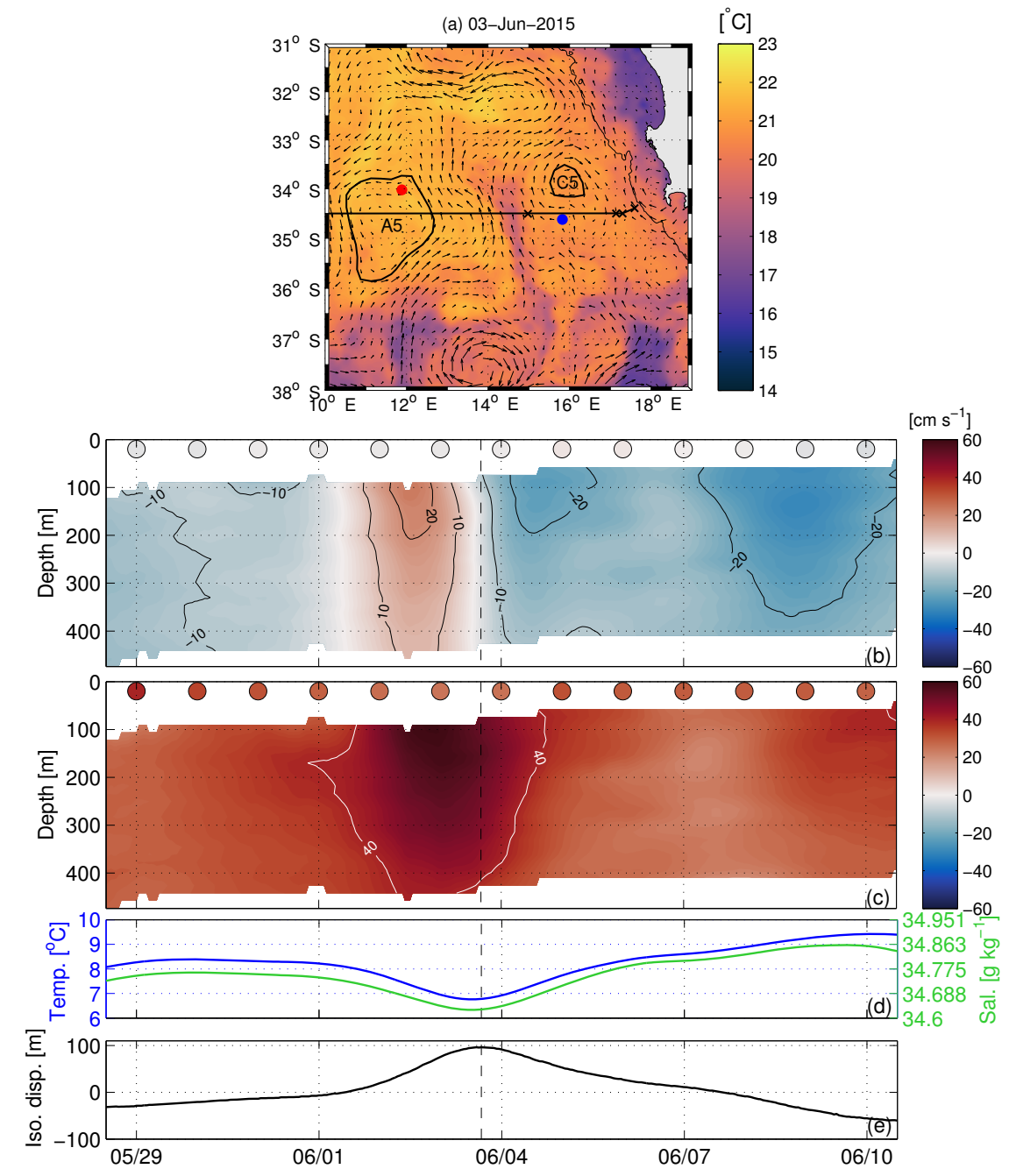

Figure 9. Cyclonic eddy: (a) SST satellite image for selected date (vertical black line on the time series). Vertical-temporal section of the $u$ component (b) and $v$ component (c) of the current speed measured from the upward-looking ADCP at M4. The colored circles at the top of the section show the $u$ and $v$ component of the current speed from altimetry data. (d) Temporal evolution of temperature (blue line) and salinity (green line) and (e) the isopycnal displacement recorded at the first SBE37 MicroCATs between 470 and $500 \mathrm{~m}$ depth.

are lower than the ones from the upward-looking ADCP but show changes of a similar order.

The case of a cyclonic eddy. The same analysis is undertaken for a second event occurring between 28 May and 10 June 2015. On 3 June 2015 (Fig. 9a), a cyclonic eddy (C5) affects the circulation along the SAMBA line. At this date, the vertical-temporal section of the $u$ component of the current speed (Fig. 9b) shows an eddy-like structure. During the time period the eddy passes across the mooring, a strong northward flow is recorded ( $v$ component - Fig. 9c; $\Theta$ and $U-$ Table 4). The core of this strong cyclonic eddy $\left(-20.0 \mathrm{~cm} \mathrm{~s}^{-1}\right.$ azimuthal velocity) extends from the surface down to $200 \mathrm{~m}$ depth. A decrease in salinity and temperature between 470 and $500 \mathrm{~m}$ depth of $0.13 \mathrm{~g} \mathrm{~kg}^{-1}$ and $1.7^{\circ} \mathrm{C}$, respectively, is recorded (Fig. 9d). This decrease can be partly explained by the $100 \mathrm{~m}$ uplift of the isopycnal layer (Fig. 9e).
From the satellite altimetry (colored circles at the top of Fig. 9b, c), the meridional component of the current speed is in good agreement with the upward-looking ADCP compared to the zonal component that shows a lower velocity.

Intrusions - dipole dynamics. From the middle of April to the end of May (Fig. 10), anticyclonic eddy A5 and cyclonic eddy $\mathrm{C} 5$ affect the circulation around M4 as a dipole. This intense dipole induces two intense northward pulses of current with meridional velocities exceeding $100 \mathrm{~cm} \mathrm{~s}^{-1}$ on 22 April and 14 May throughout the entire depth of the sampled water column. These two pulses last about 22 and 15 days. Their vertical influence is deeper than $600 \mathrm{~m}$ depth. The vertical mooring motion as evidenced by the downward shifts in the range of depths resolved by the ADCP is very intense during these two events. Although depth changes during these events $(\sim 300 \mathrm{~m})$ were substantial, the minimal variations in 

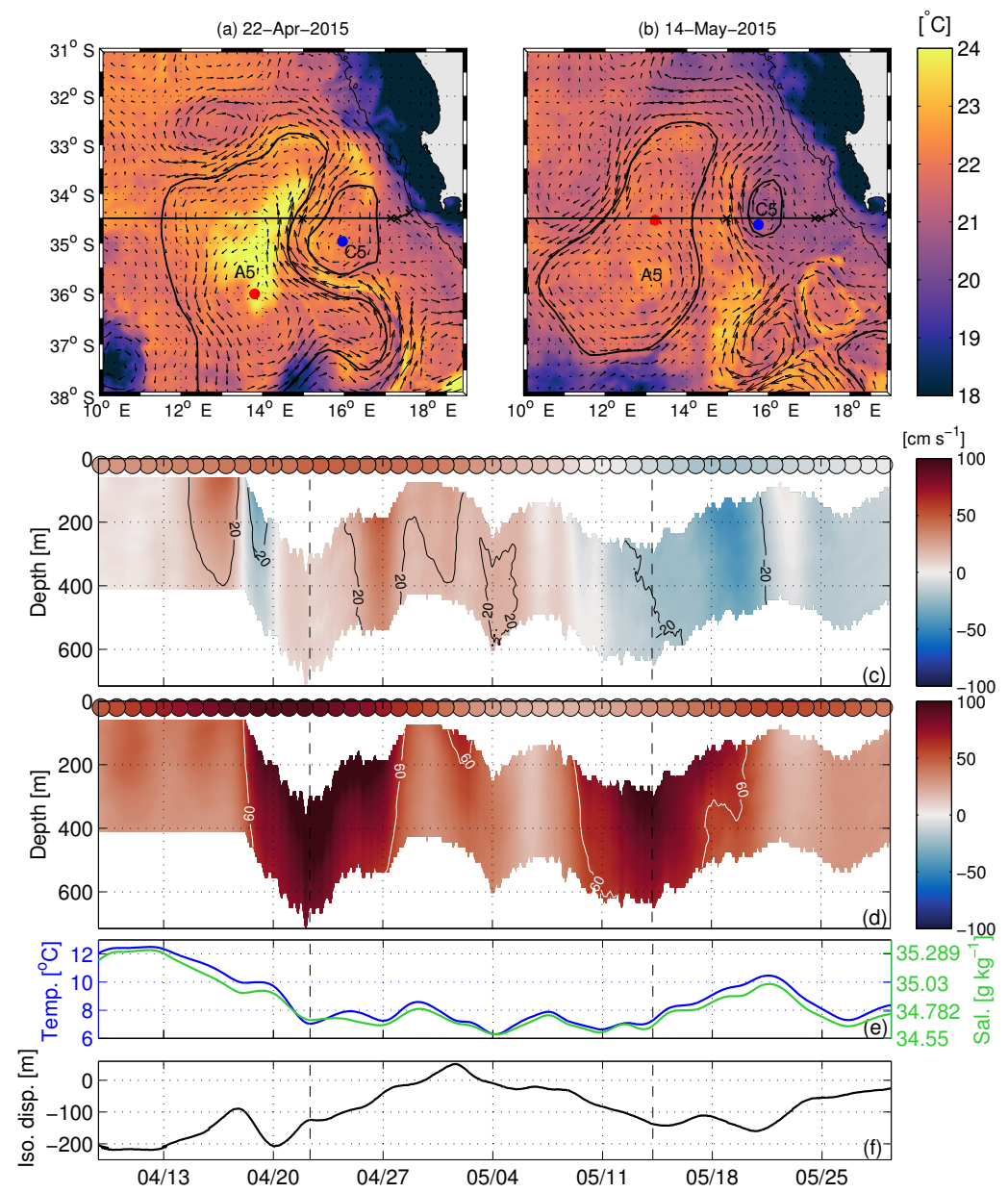

Figure 10. Intrusion water: (a, b) SST satellite images for selected dates (vertical black lines on the time series). Vertical-temporal section of the $u$ component (c) and $v$ component (d) of the current speed measured from the upward-looking ADCP at M4. The colored circles at the top of the section show the $u$ and $v$ component of the current speed from altimetry data. (e) Temporal evolution of temperature (blue line) and salinity (green line) and (f) the isopycnal displacement recorded at the first SBE37 MicroCATs between 435 and $700 \mathrm{~m}$ depth.

pitch and roll (maximum change of 5 and $4^{\circ}$ ), were well within accepted limits and indicated that the performance of the mooring is satisfactory. The altimetry data show the same intense northward current at the surface; however, there is a pronounced lag of 7 days for the second intrusion. This lag is no longer present if we consider the altimetric velocity one grid eastward $\left(0.25^{\circ}\right.$ of resolution). These two pulses of currents impact the measurements at the first SBE MicroCAT's sensor between 435 and $700 \mathrm{~m}$ depth (Fig. 10e, f) with large variations in temperature (more than $6^{\circ} \mathrm{C}$ ) and salinity $\left(\sim 0.7 \mathrm{~g} \mathrm{~kg}^{-1}\right)$ and a downshift of isopycnal layers by about $150-200 \mathrm{~m}$.

Note that the temperature and salinity anomalies for all three of these cases are much larger than the upper bound of the MicroCat's temperature and salinity biases $\left(0.14^{\circ} \mathrm{C}\right.$ and $0.01 \mathrm{~g} \mathrm{~kg}^{-1}$ ), documented in Sect. 2.

\subsection{Full water-column water mass distribution and variability}

We used the daily averaged temperature and salinity data obtained from SBE37 MicroCat's instruments on moorings to recover the regional water masses present at M4. Similarly to Lamont et al. (2015), the distribution of water masses was determined according to conservative temperature, absolute salinity and density layers, as illustrated in Fig. 11a and described in Table 5. Modified Upwelled Water (MUW) was defined according to Duncombe Rae (2005) as central shelf water upwelled along the coast and modified due to solar heating and freshwater flux. Oceanic Surface Water (OSW) was defined with the criteria of Donners et al. (2005) as salinity maximum water subducting in the western tropical Atlantic. The criteria of Donners et al. (2005) were also used to define light South Atlantic Central Water (ISACW - defined as Indian Central Water brought into the South Atlantic 
Table 5. Table with the different water masses and their definition in terms of conservative temperature, absolute salinity and density layers.

\begin{tabular}{|c|c|c|}
\hline \multicolumn{2}{|c|}{ Water mass } & Definition \\
\hline \multicolumn{2}{|l|}{ MUW } & $9.71 \leq T \leq 21.3^{\circ} \mathrm{C} ; 34.661 \leq S_{\mathrm{A}} \leq 35.647 \mathrm{~g} \mathrm{~kg}^{-1}$ \\
\hline \multicolumn{2}{|l|}{ OSW } & $\gamma^{\mathrm{n}}<26.2 \mathrm{~kg} \mathrm{~m}^{-3} ; T \geq 16.0^{\circ} \mathrm{C} ; S_{\mathrm{A}} \geq 35.647 \mathrm{~g} \mathrm{~kg}^{-1}$ \\
\hline \multicolumn{2}{|l|}{ ISACW } & $15.15 \leq T \leq 16^{\circ} \mathrm{C} ; 35.506 \leq S_{\mathrm{A}} \leq 35.764 \mathrm{~g} \mathrm{~kg}^{-1}$ \\
\hline \multicolumn{2}{|c|}{ SASTMW } & $11.69 \leq T \leq 16^{\circ} \mathrm{C} ; 35.49 \leq S_{\mathrm{A}} \leq 35.764 \mathrm{~g} \mathrm{~kg}^{-1}$ \\
\hline \multicolumn{2}{|l|}{ SAMW } & $6.32 \leq T \leq 13.18^{\circ} \mathrm{C} ; 34.78 \leq S_{\mathrm{A}} \leq 35.49 \mathrm{~g} \mathrm{~kg}^{-1}$ \\
\hline \multicolumn{2}{|c|}{ ARMW } & $11.60 \leq T \leq 17.00^{\circ} \mathrm{C} ; 35.18 \leq S_{\mathrm{A}} \leq 35.81 \mathrm{~g} \mathrm{~kg}^{-1}$ \\
\hline AAIW & $\begin{array}{l}\text { I-AAIW } \\
\text { IA-AAIW } \\
\text { A-AAIW }\end{array}$ & $\begin{array}{l}S_{\mathrm{A}} \geq 34.47 \mathrm{~g} \mathrm{~kg}^{-1} \\
34.37 \leq S_{\mathrm{A}} \leq 34.47 \mathrm{~g} \mathrm{~kg}^{-1} \\
S_{\mathrm{A}} \leq 34.37 \mathrm{~g} \mathrm{~kg}^{-1}\end{array}$ \\
\hline \multicolumn{2}{|l|}{ UCDW } & $27.55<\gamma^{n}<27.92 \mathrm{~kg} \mathrm{~m}^{-3} ; T<4.23^{\circ} \mathrm{C} ; 34.696 \leq S_{\mathrm{A}} \leq 35.916 \mathrm{~g} \mathrm{~kg}^{-1}$ \\
\hline \multicolumn{2}{|l|}{ NADW } & $27.92<\gamma^{n}<28.11 \mathrm{~kg} \mathrm{~m}^{-3}$ \\
\hline \multicolumn{2}{|l|}{ LCDW } & $28.11<\gamma^{n}<28.26 \mathrm{~kg} \mathrm{~m}^{-3}$ \\
\hline
\end{tabular}

Ocean by Agulhas Current intrusions), South Atlantic Subtropical Mode Water (SASTMW) and Subantarctic Mode Water (SAMW - with a vertical temperature gradient less than $1.6^{\circ} \mathrm{C}$ per $100 \mathrm{~m}$; Roemmich and Cornuelle, 1992). Local ventilation of Indian Central waters has been firstly identified by Arhan et al. (2011) inside different sampled Agulhas rings (Arhan et al., 1999; Gladyshev et al., 2008). This water mass has been recently defined in the study of Capuano et al. (2018) as Agulhas Ring Mode Water (ARMW) including in addition to the above two other Agulhas rings previously sampled (Duncombe Rae et al., 1996; McDonagh et al., 1999). Three different varieties of Antarctic Intermediate Water (AAIW), namely Indian AAIW (I-AAIW), IndoAtlantic AAIW (IA-AAIW) and Atlantic AAIW (A-AAIW), were characterized according to Rusciano et al. (2012). The highest salinity values in the I-AAIW variety are likely associated with Red Sea Intermediate Water (RSIW), which has been shown traveling down the Agulhas current as discontinuous filaments or confined within anticyclonic and cyclonic eddies (Roman and Lutjeharms, 2007). Upper Circumpolar Deep Water (UCDW), North Atlantic Deep Water (NADW) and Lower Circumpolar Deep Water (LCDW) were defined according to Heywood and King (2002).

Overall, the vertical distribution of water masses at M4 (colored dots - Fig. 11a) shows that SAMW is present on the southwestern African continental slope around $500 \mathrm{~m}$ depth, I-AAIW and IA-AAIW between 500 and $1000 \mathrm{~m}$, UCDW from 1000 to $1500 \mathrm{~m}$ depth, NADW between 1600 and $3000 \mathrm{~m}$, and finally LCDW below $3000 \mathrm{~m}$.

The mean vertical and zonal distributions are affected by the regional mesoscale dynamic described in the previous section. Typically a cyclonic (anticyclonic) eddy causes uplift (suppression) of isopycnal layers. The temperature and salinity relationship is highlighted for these two types of events. During the period of the anticyclonic eddies, the temperature and salinity and density values at the shallowest SBE MicroCAT sensor at M4 (red dots - Fig. 11b) show the highest range of values of the all of the time series records. During the time period of the cyclonic eddy, the values are at the opposite end, i.e., the lowest recorded densities (blue dots - Fig. 11b). While the signature of these two features is clearly separated for the two shallowest SBE MicroCAT sensors, we do not definitively prove whether these changes are associated with a thermohaline anomaly or a simple heave. During the two successive intrusions of waters due to the presence of the dipole at M4, the temperature and salinity relationship (orange and green dots - Fig. 10c) highlights a wide range of values. For this type of event the deepest sensors recorded water masses characteristics different from the ones usually sampled over the time period (Fig. 11a). The pressure record from the sensor at M4 exhibits the largest vertical variation during the time period of the dipole (Fig. 10c, d). This large vertical mooring motion adds another level of complexity to interpreting this relationship. To understand the origin of these variations, which can be associated with water trapped inside or around the eddies, vertical movement of isopycnal layers, and/or mooring motions, the full water column characteristics will be analyzed with different data sets on neutral density surfaces.

\subsection{Full water-column analysis - focus on the three case studies}

The different data sets allow us to analyze in more detail the effects of the mesoscale features described in the previous sections and successfully cross-validate the measure- 

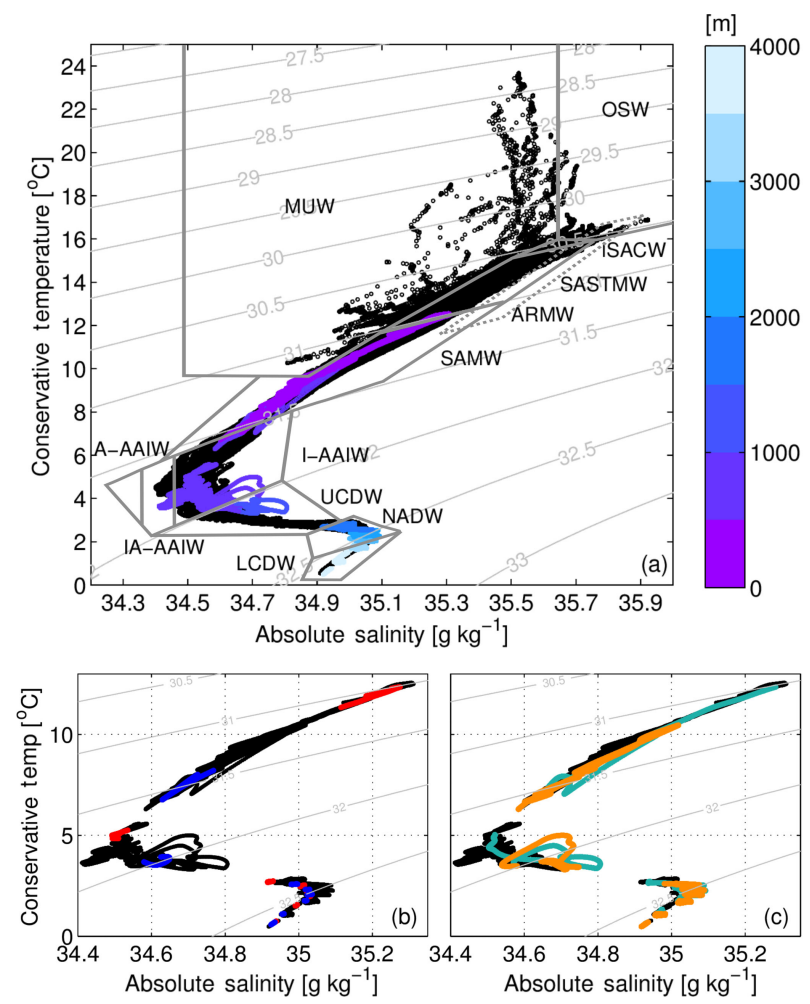

Figure 11. (a) Conservative temperature $\left({ }^{\circ} \mathrm{C}\right)$-absolute salinity $\left(\mathrm{g} \mathrm{kg}^{-1}\right)$ relationship from the hydrographic cruises sampling along the SAMBA-east array on board the RV SA Agulhas II (black dots) and from the SBE37 MicroCAT measurements at M4 (depth colored circles). The gray contours represent the potential density anomaly with a reference pressure of $1000 \mathrm{dbar}$. Water masses are indicated by gray boxes (OSW - Oceanic Surface Water; MUW - Modified Upwelled Water; ISACW - Light South Atlantic Central Water; SASTMW - South Atlantic Subtropical Mode Water; SAMW - Subantarctic Mode Water; ARMW - Agulhas Ring Mode Water; I-AAIW - Indian Antarctic Intermediate Water; IA-AAIW - Indo-Atlantic Antarctic Intermediate Water; A-AAIW - Atlantic Antarctic Intermediate Water; UCDW - Upper Circumpolar Deep Water; NADW - North Atlantic Deep Water; LCDW - Lower Circumpolar Deep Water). (b, c) Close-up views of the deep water recorded with the MicroCat illustrating the distributions observed in the anticyclonic/cyclonic cases (b) and intrusion cases (c). The colors represent the measurements during each case study(anticyclonic eddy: red; cyclonic eddy: blue; intrusions: cold water - green, warm water - orange).

ments made by the different types of moored instruments (full-depth moorings vs. CPIES).

The profiles estimated via the GEM method can be compared with the single point values of temperature and salinity from M4 sensors (eight sensors recording over the common time period, from 20 September 2014 to 11 August 2015). The reconstructed field captures the major changes in temperature and salinity variability in the upper water column. Indeed, significant correlation coefficients between these two independent data sets show values higher than 0.93 for salinity and temperature at the shallowest sensors $(\sim 450$, $900 \mathrm{~m}$ depth). At the deepest levels, the correlation coefficients range between 0.14 and 0.83 , and they are not significant at the $95 \%$ confidence level. This can be due to the small variability at the deepest levels compared to the scatter around the GEM field (Fig. 2) and the correction applied to some of the MicroCAT's data without pressure recorder during intense vertical mooring motion.

Measurements from these two data sets are compared for the three case studies described in Sect. 3.2. The conservative temperature and absolute salinity anomalies at M4 due to the presence of the eddies (anticyclone and cyclone: A5 and C5; Fig. 12a, b) and the intrusion of water that arise because of the presence of the dipole (Fig. 12c, d) are calculated relative to the hydrographic properties in "normal conditions" (just before each event occurred).

During the occupancy of A5 at M4, defined as the temporal range from $t_{0}-3 \Delta T$ to $t_{0}$ (Table $4-18-24$ March 2015), the measurements at the SBE37 MicroCATs show an increase in temperature of $1.54^{\circ} \mathrm{C}$ and salinity of $0.22 \mathrm{~g} \mathrm{~kg}^{-1}$ along the $26.73 \mathrm{~kg} \mathrm{~m}^{-3}$ neutral surface (Fig. 12a, b - red dots). The second sensor recorded a temperature anomaly of $0.48^{\circ} \mathrm{C}$. No significant anomaly is recorded for the salinity along the $27.33 \mathrm{~kg} \mathrm{~m}^{-3}$ neutral surface. The reconstructed temperature profile via the GEM method in the upper part of the water column captures a maximum temperature anomaly of $1.42^{\circ} \mathrm{C}$ along the $27.03 \mathrm{~kg} \mathrm{~m}^{-3}$ neutral surface and a salinity of $0.17 \mathrm{~g} \mathrm{~kg}^{-1}$ along the $26.7 \mathrm{~kg} \mathrm{~m}^{-3}$ neutral surface (Fig. 12a, b-red line), which is relatively well captured with the single-point measurements of the full-depth mooring. Negligible anomalies are detected in the deeper part of the water column with a neutral density larger than $27.7 \mathrm{~kg} \mathrm{~m}^{-3}$.

During the time period of $\mathrm{C} 5$, defined as before from $t_{0}-$ $3 \Delta T$ to $t_{0}$ (Table $4-31$ May-3 June 2015), the shallowest SBE37 MicroCat records negative temperature $\left(-1.43{ }^{\circ} \mathrm{C}\right)$ and salinity $\left(-0.17 \mathrm{~g} \mathrm{~kg}^{-1}\right)$ anomalies (Fig. 12a, b - blue dots). Along the $27.55 \mathrm{~kg} \mathrm{~m}^{-3}$ neutral surface, the second sensor records saltier water. Anomalies of $0.04 \mathrm{~g} \mathrm{~kg}^{-1}$ for the salinity are characteristics of I-AAIW. The hydrographic data, estimated from the CPIES, show anomalies associated with this feature of the same order. The transition between the different sign of salinity anomalies is evidenced at $27.35 \mathrm{~kg} \mathrm{~m}^{-3}$. Negligible anomalies are detected in the deeper part of the water column.

For both features (cyclonic and anticyclonic eddies), the similar temperature and salinity anomalies between the two data sets in the upper water column $\left(26-27.7 \mathrm{~kg} \mathrm{~m}^{-3}\right)$ provide evidence for the presence of different water masses trapped inside the observed mesoscale features.

During the two intrusions of water due to the presence of the dipole (first intrusion: 11-22 April 2015; second intrusion: 7-14 May 2015 - green and orange dots, Fig. 12c, d), the temperature and salinity show large anomalies at all neutral densities sampled. The largest anomalies are recorded at the first SBE37 MicroCATs for both intrusions. Dur- 


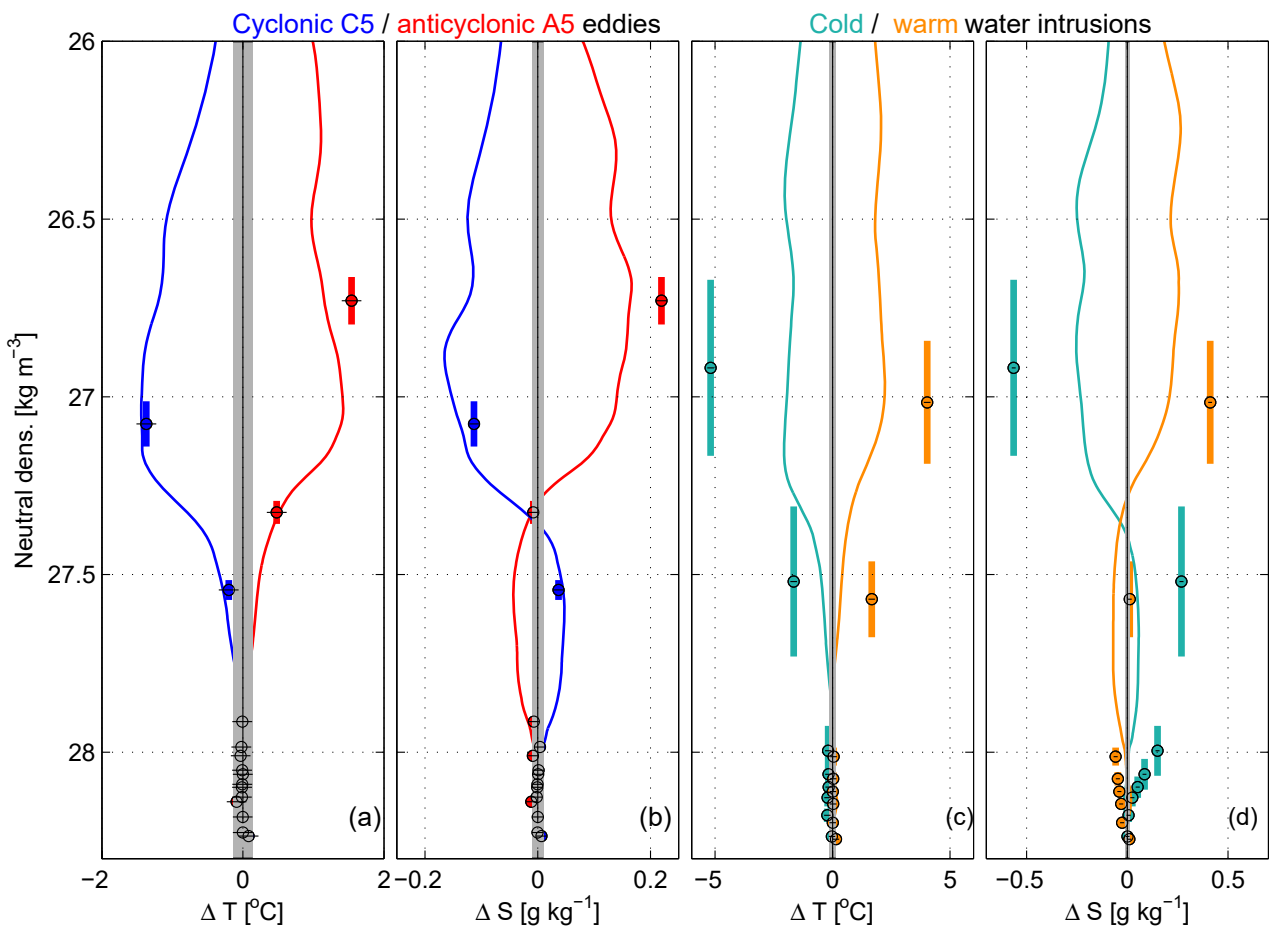

Figure 12. Vertical profiles of the conservative temperature (a, c) and absolute salinity (b, d) anomalies at M4 due to the presence of the anticyclonic and cyclonic eddies $(\mathbf{a}, \mathbf{b})$ and the two intrusions associated with the dipole $(\mathbf{c}, \mathbf{d})$. The colored dots represent the anomalies from the SBE37 MicroCATs with their estimated accuracy (horizontal black line) and their range of neutral density variability (colored boxes). The solid colored lines represent the anomalies from the reconstructed GEM fields. The gray shaded areas around the horizontal zero axis show the range of value below the estimated measurement's accuracy.

ing the second intrusion, a warmer $\left(\Delta T=4.03^{\circ} \mathrm{C}\right)$ and saltier $\left(\Delta S=0.41 \mathrm{~g} \mathrm{~kg}^{-1}\right)$ water of Indian origins appears in the upper part of the water column $\left(<27 \mathrm{~kg} \mathrm{~m}^{-3}\right.$ neutral surface). Negative anomalies during the first intrusion are very likely associated with water of subantarctic origins (anomalies of $-5.19^{\circ} \mathrm{C}$ for temperature and $-0.56 \mathrm{~g} \mathrm{~kg}^{-1}$ for salinity). As for the cyclonic eddy, during the cold intrusion the presence of high-salinity I-AAIW $\left(0.28 \mathrm{~g} \mathrm{~kg}^{-1}\right.$ in salinity) is observed along the $27.52 \mathrm{~kg} \mathrm{~m}^{-3}$ neutral surface. Interestingly from the SBE37 MicroCATs, we observe strong anomalies of salinity at the lowest neutral surface (> $\left.28 \mathrm{~kg} \mathrm{~m}^{-3}\right)$. The presence of such saltier $\left(\Delta S=0.16 \mathrm{~g} \mathrm{~kg}^{-1}\right)$ water anomalies at these depths reveal the presence of large pulses of NADW. This event influences not only the upperlayer waters but its also affects most of the water column, down to the bottom.

From the reconstructed CPIES fields, the temperature and salinity signatures of the two intrusions (Fig. 12c, d - green and orange lines) show anomalies of the same sign but 2 times smaller than the ones recorded at the MicroCATs. During these intrusions, the vertical mooring motion is very intense and is larger than the isopycnal displacement. This result is supported by the large range of neutral densities sampled by the SBE37 MicroCATs (colored boxes, Fig. 12c, d).
This range is even larger for the first two sensors, as at these shallow depths the vertical gradients of salinity and temperature are larger than horizontal gradients.

\section{Discussion and concluding remarks}

Since 2010, several efforts have been undertaken to further enhance the AMOC observation in the South Atlantic. This strategic monitoring system continues to grow along $34.5^{\circ} \mathrm{S}$, a crucial latitude to evaluate the AMOC variability and the impact of inter-ocean exchanges (Drijfhout et al., 2011). As a consequence of the limitations of high spatial and temporal resolution in in situ observations, the quantification of interocean exchange is still ongoing work and many key questions and issues remain open, such as what the characteristics of mesoscale structures are and what their impact on local water mass exchange and distribution is. In the framework of the SAMOC initiative, we provide here further investigation using a combination of satellite altimetry, full-depth moorings measurements and CPIES records.

Focusing on the SAMBA-east array region, the general circulation around South Africa has been rather well described in previous studies. Two main processes have been observed to influence this area: an equatorward shelf break frontal jet 
off the Cape Peninsula (Lutjeharms and Meeuwis, 1987; Nelson et al., 1998) and the instabilities of the Agulhas Current responsible for the spawning of mesoscale eddies propagating into the Cape Basin (Lutjeharms and Cooper, 1996; de Ruijter et al., 1999; Lutjeharms, 2006).

During the time period of our study ( $\sim 14$ months), we used a newly developed method to identify a number of eddies in our region using satellite imagery; these eddies were then confirmed to also be present in the well-known META atlas (Chelton et al., 2011). Further analysis showed that 16 large eddies were Agulhas rings, and the satellite data show that one of these rings later passes through the SAMBA-east array during the mooring time period; there were also as four anticyclonic eddies generated by the splitting of one of the rings. The Agulhas ring statistics (diameter of $170 \pm 86 \mathrm{~km}$ with translation speeds of $11 \pm 6 \mathrm{~km} \mathrm{day}^{-1}$ ) are in good agreement with previous estimates (diameter of 200-400 km - e.g., Arhan et al., 1999; translation speed of 2.9-7.3 km day ${ }^{-1}$ - e.g., Olson and Evans, 1986; Byrne et al., 1995; Goni et al., 1997; Schouten et al., 2000). The comparisons reveal that satellite data provide a reasonable description of the upper-ocean circulation along the continental slope at our mooring locations, except near the shelf break (i.e., along and inshore of the $1200 \mathrm{~m}$ isobath).

Analyses of both satellite and mooring data show that the eastern mooring array is strongly affected by the intense regional mesoscale variability. Previous studies (Arhan et al., 1999, 2011; Schouten et al., 2000; Boebel et al., 2003) have shown that Agulhas rings coexist with cold-core (cyclonic) eddies, which can contribute directly to the input of Indian water in the Atlantic (Lutjeharms et al., 2003; Arhan et al., 2011; Capuano et al., 2018). The resulting interaction of cyclonic and anticyclonic eddies can be also responsible for the extraction of warm Agulhas water filaments (Lutjeharms and Cooper, 1996; Whittle et al., 2008). These filaments may not provide more than $15 \%$ of the total mass flux of Indian Ocean waters into the South Atlantic (Lutjeharms and Cooper, 1996).

Over the measurement period from September 2014 to December 2015, the slope moorings (M2 and M3) are shown to be affected essentially by cyclonic eddies of different origins. Indeed, these moorings are affected by one cyclonic eddy generated at the Agulhas Bank (C4), one by the splitting of $\mathrm{C} 4$ and four along the South Benguela upwelling front. The offshore mooring (M4) is affected by the more complex dynamics characterizing the Cape Basin involving five Agulhas rings and two anticyclonic and cyclonic eddies both generated along the South Benguela upwelling front. The propagation of two warm surface filaments has been highlighted. The presence of several of these mesoscale features induces intense intra-seasonal upper-ocean velocity variations and water mass exchange across both the shelf and the open ocean and between the subantarctic and the subtropical frontal zones.
Our study indicates that exchange of water masses across the continental slope happens through water advection - not only via mesoscale eddies but also through wide filaments engendered by the interaction among eddies and, in particular, through the existence of intense dipoles. As illustrated in previous studies, such filaments can extend well into the thermocline and can be related to dipole dynamics (de Steur et al., 2004; Baker-Yeboah et al., 2010b). These wide intrusions cause intense north-northwestward currents affecting the whole water column. These injections are different from ordinary filaments, which exhibit a much smaller vertical extension (around $300 \mathrm{~m}$ of the water column). Among the different processes observed along the SAMBA-east array, the most significant event is the intrusion of waters of Indian Ocean and subantarctic origin due to the presence of an intense dipole.

In terms of the number of occurrences of each type of event during the 14 months of the record, we account for two intrusions of waters associated with the presence of a dipole, five Agulhas rings, six cyclonic eddies, two anticyclonic eddies and two warm filaments. Our work suggests that it is not only the advection of water within Agulhas rings or cyclonic eddies that is important but that dipole intrusions and filaments also have a significant impact on the total mass, heat and salt fluxes, and therefore, they all need to be better accounted for.

The presence of eddies, filaments and the interaction of cyclonic and anticyclonic eddies have also been described in more detail in this study with our three case studies. Following the Lilly and Rhines (2002) method, an assessment of coherent eddies, dipoles and filaments in mooring data has been achieved. This method allowed us to evaluate the eddy parameters, such as the eddy apparent radius, the direction of the mean flow and the Rossby number, all essential elements to characterize eddies in single-point measurements. The estimation of a small Rossby number $(\sim 0.1)$ associated with these features reveals that eddies are not highly nonlinear or ageostrophic by this measure, but the features are nonlinear in the sense that the corresponding Rossby number is not nil, so some ageostrophic processes are occurring. The momentum equation is then dominated by the quasi-geostrophic balance between the pressure gradient and the Coriolis forces and implies that altimetry data are adequate for investigating the dynamics of the observed mesoscale features. From altimetry data, these eddies have a maximal azimuthal velocity exceeding their translation speed, confirming that the observed mesoscale features are nonlinear by the metric of Chelton et al. (2011). This definition is maybe the most pertinent in the context of this study, since it determines the ability of the observed mesoscale features to advect a parcel of trapped fluid as they move (Flierl, 1981).

During the first two case studies, the typical impact of cyclonic and anticyclonic eddies causing, respectively, an uplift and downward motion of isopycnal layers is revealed. For the dipole case study, a downward motion of isopycnal layers is 
recorded associated with a vertical movement of the mooring.

The different properties of each type event (cyclonic eddy vs. anticyclonic eddy; cold vs. warm dipole intrusions) have been compared between full-depth moorings and CPIES measurements in density space allowing a better characterization of the full water-column hydrographic properties and the opportunity to distinguish the changes in temperature and salinity due to vertical motion (isopycnal and/or mooring displacement) vs. trapped water masses. In the upper part of the water column, the presence of Indian water trapped inside the Agulhas rings or advected within dipoles has been identified by both data sets. The intrusion of subantarctic water into the upper water layers due to the dipole dynamics is also highlighted. Associated with these upper intrusions of Indian and subantarctic waters due to the presence of dipoles, high-salinity I-AAIW at intermediate depth and NADW at the deepest level are also illustrated. The presence of intermediate high-salinity I-AAIW is also evidenced during the period of the cyclonic eddy crossing.

It has been shown that the trapping depth of rings can reach the seafloor (van Aken et al., 2003). The analyses of our tall mooring deep SBE MicroCat's data show that not only Agulhas rings but also water intrusions due to the presence of dipoles extend to $4400 \mathrm{~m}$ of depth, impacting the NADW layers and even deeper layers.

This study presents the first combination of full-depth moorings and reconstructed fields from CPIES data combined with a GEM technique in the upper water column within the eastern South Atlantic region. Here properties are well resolved by the combination of local sensors and by the GEM reconstructed fields. The reconstructed fields capture the same changes in the temperature and salinity variability in the upper water column as do the local sensors' data when mooring motion is smaller than the isopycnal displacement. Relatively small differences can be attributed to the limited vertical sampling resolution in the upper $500 \mathrm{~m}$ and the mixing associated with the mesoscale activity in the Cape Basin. When vertical mooring motion is larger than the isopycnal displacement, the local sensors sample a large range of neutral density and can overestimate the anomalies during the event compared to the GEM reconstructed fields. However, the deep water column properties remain to be analyzed with local temperature and salinity sensors. Moreover, the distance between CPIES and full-depth moorings (e.g., $210 \mathrm{~km}$ between M3 and M4) does not allow precise transport estimates - as the typical velocity decorrelation length scale is smaller than this distance $(\sim 100 \mathrm{~km}-$ e.g., Donohue et al., 2010; Meinen et al., 2017).

Finally, this work presents the first independent observation comparison between full-depth moorings and CPIES data sets along the SAMBA-east array that gives some evidence of eastern boundary buoyancy anomalies associated with migrating eddies. It also highlights the need to continuously sample the full water depth as inter-basin exchange occurs intermittently and affects the whole water column. Future investigations with longer time series at these existing sites will lead to a better understanding of the eastern boundary current variability and Indo-Atlantic exchanges. The impact of each isolated mesoscale eddy will not be adequately resolved at this scale, but the global eddy thickness flux anomalies can be improved. The CPIES records used in combination with the moored instruments in the western part of the SAMBA array will improve of our understanding of the strength and variability in the AMOC.

Data availability. Data used in this study are freely available via several web pages. Users can access the daily travel time CPIES data on the SAMOC initiative web page (www.aoml.noaa.gov/ phod/SAMOC_international/, last access: 21 August 2018). Data from the hydrographic casts and the full-depth moorings are being uploaded to the "Marine Information Management System" (data.ocean.gov.za/, last access: 21 August 2018). Data from the South African DEA are also available from Tarron Lamont (tarron.lamont@gmail.com). Argo data were collected and made freely available by the Coriolis project and programmes that contribute to it (www.coriolis.eu.org, last access: 21 August 2018). CTD profiles were obtained from the World Ocean Database (www.nodc. noaa.gov/OC5/indprod.html, last access: 21 August 2018, Boyer et al., 2013). The altimeter products were produced by Ssalto/Duacs and distributed by Aviso, with support from CNES (www.aviso. oceanobs.com/duacs/, last access: 21 August 2018). Odyssea SST data were produced by the Medspiration project and were obtained from the Centre de Recherche et d'Exploitation Satellitaire (CERSAT, cersat.ifremer.fr/data/, last access: 21 August 2018), at IFREMER, Plouzane (France). The Mesoscale Eddy Trajectory Atlas products were produced recently by Centre National d'Etudes Spatiales (CNES) Collecte Localisations Satellites (CLS) in the Data Unification and Altimeter Combination System (DUACS) system and distributed by Archiving, Validation and Interpretation of Satellite Oceanographic Data (AVISO)(www.aviso.altimetry.fr/, last access: 21 August 2018) with support from CNES, in collaboration with Oregon State University with support from NASA.

Author contributions. MK took the lead in analyzing the data and writing the manuscript. TL, SS, IA, and MR designed and planned the array, with assistance from TT and MvdB. RL developed the eddy detection method and performed the eddy statistics. All authors helped shape the research, and were involved in the analysis and in preparing the manuscript.

Competing interests. The authors declare that they have no conflict of interest.

Acknowledgements. The authors would like to express their great appreciation to the captain, officers and crew of the research vessels which have supported this program to date, including the South African research vessels the RV Algoa and the RV SA Agulhas II. We are warmly grateful to the technical staff who worked on the 
preparation, deployment and the recovery of the instruments. And our thanks to those who have helped coordinate these challenging international cruise collaborations. The authors acknowledge the support of grants from the NRF/SANAP-SAMOC-SA programme. Marion Kersalé acknowledges support from a NRF grant via a South African post-doctoral fellowship. Marion Kersalé's work on this study was carried out in part under the auspices of the Cooperative Institute for Marine and Atmospheric Studies (CIMAS), a Cooperative Institute of the University of Miami and the National Oceanic and Atmospheric Administration (NOAA), cooperative agreement NA10OAR4320143. Marion Kersalé also acknowledges support from the NOAA Atlantic Oceanographic and Meteorological Laboratory. This work was also supported by the European Union's Horizon 2020 research and innovation programme under grant agreement no. 633211 (AtlantOS) and the 11-ANR-56-004 grant for Sabrina Speich. The authors thank Renellys C. Perez, Chris S. Meinen and Jonathan Lilly for precious help, comments and useful discussions. Finally, we thank the editor and the three reviewers of this paper for their constructive comments.

Edited by: Piers Chapman

Reviewed by: Johannes Karstensen and two anonymous referees

\section{References}

Ahlnäs, K., Royer, T. C., and George, T. H.: Multiple dipole eddies in the Alaska Coastal Current detected with Landsat thematic mapper data, J. Geophys. Res., 92, 13041-13047, https://doi.org/10.1029/JC092iC12p13041, 1987.

Ansorge, I. J., Speich, S., Lutjeharms, J. R. E., Goni, G. J., Rautenbach, C. D. W., Froneman, P. W., Rouault, M., and Garzoli, S.: Monitoring the oceanic flow between Africa and Antarctica: report of the first GoodHope cruise: research in action, S. Afr. J. Sci., 101, 29-35, 2005.

Ansorge, I. J., Baringer, M. O., Campos, E. J. D., Dong, S., Fine, R. A., Garzoli, S. L., Goni, G., Meinen, C. S., Perez, R. C., Piola, A. R., Roberts, M. J., Speich, S., Sprintall, J., Terre, T., and Van den Berg, M. A.: Basin-Wide Oceanographic Array Bridges the South Atlantic, Eos T. Am. Geophys. Un., 95, 5354, https://doi.org/10.1002/2014EO060001, 2014.

Arhan, M., Mercier, H., and Lutjeharms, J. R. E.: The disparate evolution of three Agulhas rings, J. Geophys. Res., 104, 2098721005, https://doi.org/10.1029/1998JC900047, 1999.

Arhan, M., Speich, S., Messager, C., Dencausse, G., Fine, R., and Boye, M.: Anticyclonic and cyclonic eddies of subtropical origin in the subantarctic zone south of Africa, J. Geophys. Res., 116, C11004, https://doi.org/10.1029/2011JC007140, 2011.

Baker-Yeboah, S., Flierl, G. R., Sutyrin, G. G., and Zhang, Y.: Transformation of an Agulhas eddy near the continental slope, Ocean Sci., 6, 143-159, https://doi.org/10.5194/os-6-143-2010, 2010a.

Baker-Yeboah, S., Byrne, D. A., and Watts, D. R.: Observations of mesoscale eddies in the South Atlantic Cape Basin: Baroclinic and deep barotropic eddy variability, J. Geophys. Res., 115, C12069, https://doi.org/10.1029/2010JC006236, 2010 b.
Bang, N. D.: Characteristics of an intense ocean frontal system in the upwell regime west of Cape Town, Tellus, 25, 256-265, https://doi.org/10.3402/tellusa.v25i3.9659, 1973.

Beal, L. M., De Ruijter, W. P., Biastoch, A., and Zahn, R.: On the role of the Agulhas system in ocean circulation and climate, Nature, 472, 429-436, https://doi.org/10.1038/nature09983, 2011.

Beal, L. M., Elipot, S., Houk, A., and Leber, G. M.: Capturing the transport variability of a western boundary jet: Results from the Agulhas Current Time-Series Experiment (ACT), J. Phys. Oceanogr., 45, 1302-1324, https://doi.org/10.1175/JPO-D-140119.1, 2015.

Biastoch, A., Böning, C. W., and Lutjeharms, J. R. E.: Agulhas Leakage dynamics affects decadal variability in Atlantic overturning circulation, Nature, 456, 489-492, https://doi.org/10.1038/nature07426, 2008.

Biastoch, A., Durgadoo, J. V., Morrison, A. K., Van Sebille, E., Weijer, W., and Griffies, S. M.: Atlantic multi-decadal oscillation covaries with Agulhas leakage, Nature, 6, 10082, https://doi.org/10.1038/ncomms10082, 2015.

Boebel, O., Lutjeharms, J., Schmid, C., Zenk, W., Rossby, T., and Barron, C.: The Cape Cauldron: a regime of turbulent inter-ocean exchange. Deep-Sea Res. Pt. II, 50, 57-86, https://doi.org/10.1016/S0967-0645(02)00379-X, 2003.

Boyd, A. J., Taunton-Clark, J., and Oberholster, G. P. J.: Spatial features of the near-surface and midwater circulation patterns off western and southern South Africa and their role in the life histories of various commercially fished species, Afr. J. Mar. Sci., 12, 189-206, https://doi.org/10.2989/02577619209504702, 1992.

Boyer, T. P., Antonov, J. I., Baranova, O. K., Coleman, C., Garcia, H. E., Grodsky, A., Johnson, D. R., Locarnini, R. A., Mishonov, A. V., O’Brien, T .D., Paver, C. R., Reagan, J. R., Seidov, D., Smolyar, I. V., and Zweng, M. M.: World Ocean Database 2013, NOAA Atlas NESDIS 72, edited by: Levitus, S. and Mishonov, A., Silver Spring, MD, 209 pp., https://doi.org/10.7289/V5NZ85MT, 2013.

Byrne, D. A., Gordon, A. L., and Haxby, W. F.: Agulhas eddies: A synoptic view using Geosat ERM data, J. Phys. Oceanogr., 25, 902-917, https://doi.org/10.1175/15200485(1995)025<0902:AEASVU>2.0.CO;2, 1995.

Capuano, T. A., Speich, S., Carton, X., and Blanke, B.: Mesoscale and Submesoscale Processes in the Southeast Atlantic and Their Impact on the Regional Thermohaline Structure, J. Geophys. Res.-Oceans, 123, 1937-1961, https://doi.org/10.1002/2017JC013396, 2018.

Chaigneau, A., Gizolme, A., and Grados, C.: Mesoscale eddies off Peru in altimeter records: Identification algorithms and eddy spatio-temporal patterns, Prog. Oceanogr., 79, 106-119, https://doi.org/10.1016/j.pocean.2008.10.013, 2008.

Chaigneau, A., Eldin, G., and Dewitte, B.: Eddy activity in the four major upwelling systems from satellite altimetry (1992-2007), Prog. Oceanogr., 83, 117-123, https://doi.org/10.1016/j.pocean.2009.07.012, 2009.

Chaigneau, A., Le Texier, M., Eldin, G., Grados, C., and Pizarro, O.: Vertical structure of mesoscale eddies in the eastern South Pacific Ocean: A composite analysis from altimetry and Argo profiling floats, J. Geophys. Res., 116, C11025, https://doi.org/10.1029/2011JC007134, 2011. 
Chelton, D. B., Schlax, M. G., and Samelson, R. M.: Global observations of nonlinear mesoscale eddies, Prog. Oceanogr., 91, 167-216, https://doi.org/10.1016/j.pocean.2011.01.002, 2011.

Chereskin, T. K., Donohue, K. A., Watts, D. R., Tracey, K. L., Firing, Y. L., and Cutting, A. L.: Strong bottom currents and cyclogenesis in Drake Passage, Geophys. Res. Lett., 36, L23602, https://doi.org/10.1029/2009GL040940, 2009.

Chidichimo, M. P., Donohue, K. A., Watts, D. R., and Tracey, K. L.: Baroclinic transport time series of the Antarctic Circumpolar Current measured in Drake Passage, J. Phys. Oceanogr., 44, 1829-1853, https://doi.org/10.1175/JPO-D-13-071.1, 2014.

de Jong, M. F., Bower, A. S., and Furey, H. H.: Two years of observations of warm-core anticyclones in the Labrador Sea and their seasonal cycle in heat and salt stratification, J. Phys. Oceanogr., 44, 427-444, https://doi.org/10.1175/JPO-D-13-070.1, 2014.

Dencausse, G., Arhan, M., and Speich, S.: Routes of Agulhas rings in the southeastern Cape Basin, Deep-Sea Res. Pt. I, 57, 14061421, https://doi.org/10.1016/j.dsr.2010.07.008, 2010.

de Ruijter, W. P. M., Biastoch, A., Drijfhout, S. S., Lutjeharms, J. R. E., Matano, R. P., Pichevin, T., van Leeuwen, P. J., and Weijer, W.: Indian-Atlantic interocean exchange: Dynamics, estimation and impact, J. Geophys. Res., 104, 20885-20910, https://doi.org/10.1029/1998JC900099, 1999.

de Ruijter, W. P. M., van Aken, H. M., Beier, E. J., Lutjeharms, J. R., Matano, R. P., and Schouten, M. W.: Eddies and dipoles around South Madagascar: formation, pathways and large-scale impact, Deep-Sea Res. Pt. I, 51, 383-400, https://doi.org/10.1016/j.dsr.2003.10.011, 2004.

de Steur, L., Van Leeuwen, P. J., and Drijfhout, S. S.: Tracer leakage from modeled Agulhas rings, J. Phys. Oceanogr., 34, 1387-1399, https://doi.org/10.1175/15200485(2004)034<1387:TLFMAR>2.0.CO;2, 2004.

Donners, J., Drijfhout, S. S., and Hazeleger, W.: Water mass transformation and subduction in the South Atlantic, J. Phys. Oceanogr., 35, 1841-1860, https://doi.org/10.1175/JPO2782.1, 2005.

Donohue, K. A., Watts, D. R., Tracey, K. L., Greene, A. D., and Kennelly, M.: Mapping circulation in the Kuroshio Extension with an array of current and pressure recording inverted echo sounders, J. Atmos. Ocean. Tech., 27, 507-527, https://doi.org/10.1175/2009JTECHO686.1, 2010.

Donohue, K. A., Tracey, K. L., Watts, D. R., Chidichimo, M. P., and Chereskin, T. K.: Mean Antarctic Circumpolar Current transport measured in Drake Passage, Geophys. Res. Lett., 43, 1176011767, https://doi.org/10.1002/2016GL070319, 2016.

Drijfhout, S. S., Weber, S. L., and van der Swaluw, E.: The stability of the MOC as diagnosed from model projections for preindustrial, present and future climates, Clim. Dynam., 37, 15751586, https://doi.org/10.1007/s00382-010-0930-z, 2011.

Duncombe Rae, C. M.: Agulhas retroflection rings in the South Atlantic Ocean: an overview, Afr. J. Mar. Sci., 11, 327-344, https://doi.org/10.2989/025776191784287574, 1991.

Duncombe Rae, C. M.: A demonstration of the hydrographic partition of the Benguela upwelling ecosystem at $26^{\circ} 40^{\prime} \mathrm{S}$, Afr. J. Mar. Sci., 27, 617-628, https://doi.org/10.2989/18142320509504122, 2005.

Duncombe Rae, C. D., Shillington, F. A., Agenbag, J. J., TauntonClark, J., and Gründlingh, M. L.: An Agulhas ring in the South Atlantic Ocean and its interaction with the Benguela up- welling frontal system, Deep-Sea Res. Pt. I, 39, 2009-2027, https://doi.org/10.1016/0198-0149(92)90011-H, 1992.

Duncombe Rae, C. M., Garzoli, S. L., and Gordon, A. L.: The eddy field of the southeast Atlantic Ocean: A statistical census from the Benguela Sources and Transports Project, J. Geophys. Res., 101, 11949-11964, https://doi.org/10.1029/95JC03360, 1996.

Elipot, S. and Beal, L. M.: Observed Agulhas Current sensitivity to interannual and long-term trend atmospheric forcings, J. Climate, 31, 3077-3098, https://doi.org/10.1175/JCLI-D-170597.1, 2018.

Faghmous, J. H., Frenger, I., Yao, Y., Warmka, R., Lindell, A., and Kumar, V.: A daily global mesoscale ocean eddy dataset from satellite altimetry, Scientific Data, 2, 150028, https://doi.org/10.1038/sdata.2015.28, 2015.

Flierl, G. R.: Particle motions in large-amplitude wave fields, Geophys. Astro. Fluid, 18, 39-74, https://doi.org/10.1080/03091928108208773, 1981.

Garzoli, S. L. and Gordon, A. L.: Origins and variability of the Benguela Current, J. Geophys. Res., 101, 897-906, https://doi.org/10.1029/95JC03221, 1996.

Garzoli, S. L. and Matano, R.: The South Atlantic and the Atlantic meridional overturning circulation, Deep-Sea Res. Pt. II, 58, 1837-1847, https://doi.org/10.1016/j.dsr2.2010.10.063, 2011.

Gladyshev, S., Arhan, M., Sokov, A., and Speich, S.: A hydrographic section from South Africa to the southern limit of the Antarctic Circumpolar Current at the Greenwich meridian, Deep-Sea Res. Pt. I, 55, 1284-1303, https://doi.org/10.1016/j.dsr.2008.05.009, 2008.

Goni, G. J., Garzoli, S. L., Roubicek, A. J., Olson, D. B., and Brown, O. B.: Agulhas ring dynamics from TOPEX/POSEIDON satellite altimeter data, J. Mar. Res., 55, 861-883, https://doi.org/10.1357/0022240973224175, 1997.

Gordon, A. L.: Indian-Atlantic transfer of thermocline water at the Agulhas Retroflection, Science, 227, 1030-1033, https://doi.org/10.1126/science.227.4690.1030, 1985.

Gordon, A. L.: Interocean exchange of thermocline water, J. Geophys. Res., 91, 5037-5046, https://doi.org/10.1029/JC091iC04p05037, 1986.

Gordon, A. L. and Haxby, W. F.: Agulhas eddies invade the South Atlantic: Evidence from Geosat altimeter and shipboard conductivity-temperature-depth survey, J. Geophys. Res., 95, 3117-3125, https://doi.org/10.1029/JC095iC03p03117, 1990.

Gordon, A. L., Weiss, R. F., Smethie, W. M., and Warner, M. J.: Thermocline and intermediate water communication between the South Atlantic and Indian Oceans, J. Geophys. Res., 97, 72237240, https://doi.org/10.1029/92JC00485, 1992.

Hall, C. and Lutjeharms, J. R. E.: Cyclonic eddies identified in the Cape Basin of the South Atlantic Ocean, J. Marine Syst., 851 10, https://doi.org/10.1016/j.jmarsys.2010.10.003, 2011.

Heywood, K. J. and King, B. A.: Water masses and baroclinic transports in the South Atlantic and Southern oceans, J. Mar. Res., 60, 639-676, https://doi.org/10.1357/002224002762688687, 2002.

Hogg, N. G. and Stommel, H. M.: The heton, an elementary interaction between discrete baroclinic geostrophic vortices, and its implications concerning eddy heat-flow, P. Roy. Soc. Lond. A Mat., 397, 1-20, 1985.

Hooker, S. B. and Brown, J. W.: Warm core ring dynamics derived from satellite imagery, J. Geophys. Res., 99, 25181-25194, https://doi.org/10.1029/94JC02171, 1994. 
Hooker, S. B., Brown, J. W., Kirwan, A. D., Lindemann, G. J., and Mied, R. P.: Kinematics of a warm-core dipole ring, J. Geophys. Res., 100, 24797-24809, https://doi.org/10.1029/95JC02900, 1995.

Hutchinson, K., Swart, S., Meijers, A., Ansorge, I., and Speich, S.: Decadal-scale thermohaline variability in the Atlantic sector of the Southern Ocean, J. Geophys. Res., 121, 3171-3189, https://doi.org/10.1002/2015JC011491, 2016.

IOC, SCOR and IAPSO: The international thermodynamic equation of seawater - 2010: Calculation and use of thermodynamic properties, Intergovernmental Oceanographic Commission (IOC), Manuals and Guides No. 56, UNESCO, 196 pp., 2010.

Kanzow, T., Send, U., Zenk, W., Chave, A. D., and Rhein, M.: Monitoring the integrated deep meridional flow in the tropical North Atlantic: Long-term performance of a geostrophic array, Deep-Sea Res. Pt. I, 53, 528-546, https://doi.org/10.1016/j.dsr.2005.12.007, 2006.

Lamont, T., Hutchings, L., Van Den Berg, M. A., Goschen, W. S., and Barlow, R. G.: Hydrographic variability in the St. Helena Bay region of the southern Benguela ecosystem. J. Geophys. Res., 120, 2920-2944, https://doi.org/10.1002/2014JC010619, 2015.

Lilly, J. M. and Rhines, P. B.: Coherent eddies in the Labrador Sea observed from a mooring, J. Phys. Oceanogr., $\quad 32, \quad 585-598, \quad$ https://doi.org/10.1175/15200485(2002)032<0585:CEITLS>2.0.CO;2, 2002.

Lilly, J. M., Rhines, P. B., Schott, F., Lavender, K., Lazier, J., Send, U., and D'Asaro, E.: Observations of the Labrador Sea eddy field, Prog. Oceanogr., 59, 75-176, https://doi.org/10.1016/j.pocean.2003.08.013, 2003.

Locarnini, R. A., Mishonov, A. V., Antonov, J. I., Boyer, T. P., Garcia, H. E., Baranova, O. K., Zweng, M. M. , Paver, C. R., Reagan, J. R., Johnson, D. R., Hamilton, M., and Seidov, D.: World Ocean Atlas 2013, Volume 1: Temperature, edited by: Levitus, S. and Mishonov, A., NOAA Atlas NESDIS 73, 40 pp., 2013.

Lutjeharms, J. R. E.: The Agulhas Current, Springer Berlin Heidelberg, 329 pp., https://doi.org/10.1007/3-540-37212-1, 2006.

Lutjeharms, J. R. E. and Cooper, J.: Interbasin leakage through Agulhas Current filaments, Deep-Sea Res. Pt. I, 43, $213217-$ 215238, https://doi.org/10.1016/0967-0637(96)00002-7, 1996.

Lutjeharms, J. R. E. and Meeuwis, J. M.: The extent and variability of South-East Atlantic upwelling, Afr. J. Mar. Sci., 5, 51-62, https://doi.org/10.2989/025776187784522621, 1987.

Lutjeharms, J. R. E., Boebel, O., and Rossby, T.: KAPEX: an international experiment to study deep water movement around southern Africa, S. Afr. J. Sci., 93, 377-381, 1997.

Lutjeharms, J. R. E., Boebel, O., and Rossby, H. T.: Agulhas cyclones, Deep-Sea Res., Pt. II, 50, 13-34, https://doi.org/10.1016/S0967-0645(02)00378-8, 2003.

Matano, R. P. and Beier, E. J.: A kinematic analysis of the Indian/Atlantic interocean exchange, Deep-Sea Res. Pt. II, 50, 229-249, https://doi.org/10.1016/S0967-0645(02)00395-8, 2003.

McDonagh, E. L., Heywood, K. J., and Meredith, M. P.: On the structure, paths, and fluxes associated with Agulhas rings, J. Geophys. Res., 104, 21007-21020, https://doi.org/10.1029/1998JC900131, 1999.
Meinen, C. S and Watts, D. R.: Vertical structure and transport on a transect across the North Atlantic Current near $42^{\circ} \mathrm{N}$ : Time series and mean, J. Geophys. Res., 105, 21869-21891, https://doi.org/10.1029/2000JC900097, 2000.

Meinen, C. S., Luther, D. S., and Baringer, M. O.: Structure, transport and potential vorticity of the Gulf Stream at $6^{\circ} \mathrm{W}$ : Revisiting older data sets with new techniques, Deep-Sea Res. Pt. I, 56, 41-60, https://doi.org/10.1016/j.dsr.2008.07.010, 2009.

Meinen, C. S., Piola, A. R., Perez, R. C., and Garzoli, S. L.: Deep Western Boundary Current transport variability in the South Atlantic: preliminary results from a pilot array at $34.5^{\circ} \mathrm{S}$, Ocean Sci., 8, 1041-1054, https://doi.org/10.5194/os-8-10412012, 2012.

Meinen, C. S., Speich, S., Perez, R. C., Dong, S., Piola, A. R., Garzoli, S. L., Baringer, M. O., Gladyshev, S., and Campos, E. J. D.: Temporal variability of the meridional overturning circulation at $34.5^{\circ} \mathrm{S}$ : Results from two pilot boundary arrays in the South Atlantic, J. Geophys. Res., 118, 6461-6478, https://doi.org/10.1002/2013JC009228, 2013.

Meinen, C. S., Garzoli, S. L., Perez, R. C., Campos, E., Piola, A. R., Chidichimo, M. P., Dong, S., and Sato, O. T.: Characteristics and causes of Deep Western Boundary Current transport variability at $34.5^{\circ} \mathrm{S}$ during 2009-2014, Ocean Sci., 13, 175-194, https://doi.org/10.5194/os-13-175-2017, 2017.

Meinen, C. S., Speich, S., Piola, A. R., Ansorge, I. J., Campos, E. J. D., Kersalé , M., Terre, T., Chidichimo, M. P., Lamont, T., Sato, O. T., Perez, R. C., Valla, D., van den Berg, M. A., Le Hénaff, M., Dong, S., and Garzoli, S. L.: Meridional Overturning Circulation transport variability at $34.5^{\circ} \mathrm{S}$ during $2009-$ 2017: Baroclinic and barotropic flows and the dueling influence of the boundaries, Geophys. Res. Lett., 45, 4180-4188, https://doi.org/10.1029/2018GL077408, 2018.

Millot, C. and Taupier-Letage, I.: Circulation in the Mediterranean sea, in: The Mediterranean Sea, Springer, Berlin, Heidelberg, 323-334, 2005.

Nelson, G., Boyd, A. J., Agenbag, J. J., and Duncombe Rae, C. M.: An upwelling filament north-west of Cape Town, South Africa, Afr. J. Mar. Sci., 19, 75-88, https://doi.org/10.2989/025776198784126953, 1998.

Nencioli, F., Dong, C., Dickey, T., Washburn, L., and McWilliams, J. C.: A vector geometry-based eddy detection algorithm and its application to a high-resolution numerical model product and high-frequency radar surface velocities in the Southern California Bight, J. Atmos. Ocean. Tech., 27, 564-579, https://doi.org/10.1175/2009JTECHO725.1, 2010.

Olson, D. B. and Evans, R. H.: Rings of the Agulhas current, Deep-Sea Res. Pt. I, 33, 27-42, https://doi.org/10.1016/01980149(86)90106-8, 1986.

Pallàs-Sanz, E. and Viúdez, Á.: Three-dimensional ageostrophic motion in mesoscale vortex dipoles, J. Phys. Oceanogr., 37, 84105, https://doi.org/10.1175/JPO2978.1, 2007.

Pegliasco, C., Chaigneau, A., and Morrow, R.: Main eddy vertical structures observed in the four major Eastern Boundary Upwelling Systems, J. Geophys. Res., 120, 6008-6033, https://doi.org/10.1002/2015JC010950, 2015.

Penven, P., Lutjeharms, J. R. E., Marchesiello, P., Roy, C., and Weeks, S. J.: Generation of cyclonic eddies by the Agulhas Current in the lee of the Agulhas Bank, Geophys. Res. Lett., 28, 1055-1058, https://doi.org/10.1029/2000GL011760, 2001. 
Perez, R. C., Garzoli, S. L., Meinen, C. S., and Matano, R. P.: Geostrophic velocity measurement techniques for the meridional overturning circulation and meridional heat transport in the South Atlantic, J. Atmos. Ocean. Tech., 28, 1504-1521, https://doi.org/10.1175/JTECH-D-11-00058.1, 2011.

Pujol, M.-I., Faugère, Y., Taburet, G., Dupuy, S., Pelloquin, C., Ablain, M., and Picot, N.: DUACS DT2014: the new multimission altimeter data set reprocessed over 20 years, Ocean Sci., 12, 1067-1090, https://doi.org/10.5194/os-12-1067-2016, 2016.

Richardson, P. L. and Garzoli, S. L.: Characteristics of intermediate water flow in the Benguela current as measured with RAFOS floats, Deep-Sea Res. Pt. II, 50, 87-118, https://doi.org/10.1016/S0967-0645(02)00380-6, 2003.

Richardson, P. L., Lutjeharms, J. R. E., and Boebel, O.: Introduction to the "Inter-ocean exchange around southern Africa", Deep-Sea Res. Pt. I, 50, 1-12, https://doi.org/10.1016/S09670645(02)00376-4, 2003.

Robinson, A. R. (Ed.): Overview and summary of eddy science, in: Eddies in marine science, Springer, Berlin, Heidelberg, 3-15, https://doi.org/10.1007/978-3-642-69003-7_1, 1983.

Roemmich, D. and Cornuelle, B.: The subtropical mode waters of the South Pacific Ocean, J. Phys. Oceanogr., 22, 1178-1187, https://doi.org/10.1175/15200485(1992)022<1178:TSMWOT>2.0.CO;2, 1992.

Roman, R. E. and Lutjeharms, J. R. E.: Red sea intermediate water at the Agulhas current termination, Deep-Sea Res. Pt. I, 54, 1329-1340, https://doi.org/10.1016/j.dsr.2007.04.009, 2007.

Rusciano, E., Speich, S., and Ollitrault, M.: Interocean exchanges and the spreading of Antarctic Intermediate Water south of Africa, J. Geophys. Res., 117, C10010, https://doi.org/10.1029/2012JC008266, 2012.

Schiermeier, Q.: Oceans under surveillance, Nature, 497, 167-169, 2013.

Schouten, M. W., de Ruijter, W. P. M., van Leeuwen, P. J., and Lutjeharms, J. R. E.: Translation, decay and splitting of Agulhas rings in the southeastern Atlantic Ocean, J. Geophys. Res., 105, 21913-21925, https://doi.org/10.1029/1999JC000046, 2000.

Shannon, L. V. and Nelson, G.: The Benguela: large scale features and processes and system variability, in: The South Atlantic, Springer, Berlin, Heidelberg, 163-210, https://doi.org/10.1007/978-3-642-80353-6_9, 1996.

Spall, M. A.: Frontogenesis, subduction, and cross-front exchange at upper ocean fronts, J. Geophys. Res., 100, 2543-2557, https://doi.org/10.1029/94JC02860, 1995.

Speich, S., Arhan, M., Ansorge, I., Boebel, O., Sokov, A., Gladyshev, S., Farbach, E., Byrne, D., Klepikov, A., and Garzoli, S.: GOODHOPE/Southern Ocean: A study and monitoring of the Indotlantic connections, Mercator Newsletter, 27, 29-41, October 2007.

Speich, S., Garzoli, S., Piola, A., and the SAMOC community: A monitoring system for the South Atlantic as a component of the MOC, in: Proceedings of OceanObs'09: Sustained Ocean Observations and Information for Society (Annex), Venice, Italy, 21-25 September 2009, edited by: Hall, J., Harrison, D. E., and Stammer, D., ESA Publication WPP-306, 2010.

Sutherland, D. A., Straneo, F., Lentz, S. J., and SaintLaurent, P.: Observations of fresh, anticyclonic eddies in the Hudson Strait outflow, J. Marine Syst., 88, 375-384, https://doi.org/10.1016/j.jmarsys.2010.12.004, 2011.
Swart, S., Speich, S., Ansorge, I. J., Goni, G. J., Gladyshev, S., and Lutjeharms, J. R.: Transport and variability of the Antarctic Circumpolar Current south of Africa, J. Geophys. Res., 113, C09014, https://doi.org/10.1029/2007JC004223, 2008.

Thomson, R. E. and Emery, W. J.: Chapter 3 - Statistical Methods and Error Handling, in: Data analysis methods in physical oceanography, 3rd edn., Elsevier, Boston, 219-311 https://doi.org/10.1016/B978-0-12-387782-6.00003-X, 2014.

Ursella, L., Kovačević, V., and Gačić, M.: Footprints of mesoscale eddy passages in the Strait of Otranto (Adriatic Sea), J. Geophys. Res., 116, C04005, https://doi.org/10.1029/2010JC006633, 2011.

Valla, D., Piola, A. R., Meinen, C. S., and Campos, E.: Strong mixing and recirculation in the northwestern Argentine Basin, J. Geophys. Res.-Oceans, 123, 4624-4648, https://doi.org/10.1029/2018JC013907, 2018.

van Aken, H. M., Van Veldhoven, A. K., Veth, C., De Ruijter, W. P. M., Van Leeuwen, P. J., Drijfhout, S. S., Whittle, C. P., and Rouault, M.: Observations of a young Agulhas ring, Astrid, during MARE in March 2000, Deep-Sea Res. Pt. II, 50, 167-195, https://doi.org/10.1016/S0967-0645(02)00383-1, 2003.

van Ballegooyen, R. C., Gründlingh, M. L., and Lutjeharms, J. R. E.: Eddy fluxes of heat and salt from the southwest Indian Ocean into the southeast Atlantic Ocean: A case study, J. Geophys. Res., 99, 14053-14070, https://doi.org/10.1029/94JC00383, 1994.

van den Berg, M.: Cruise report: SAMBA Moorings \& Monitoring Line, RS Algoa Voyage 221, 30 November-6 December 2015, Department of Environmental Affairs, RSA, Cruise Reports, available at: http://www.aoml.noaa.gov/phod/SAMOC_ international/documents/Cruise_Report_alg221_final.pdf (last access: 14 August 2018), 2015.

van Sebille, E., England, M. H., and Froyland, G.: Origin, dynamics and evolution of ocean garbage patches from observed surface drifters, Environ. Res. Lett, 7, 044040, https://doi.org/10.1088/1748-9326/7/4/044040, 2012.

Veitch, J., Hermes, J., Lamont, T., Penven, P., and Dufois, F.: Shelf-edge jet currents in the southern Benguela: A modelling approach, J. Marine Syst., https://doi.org/10.1016/j.jmarsys.2017.09.003, in press, 2017.

Watts, D. R. and Kontoyiannis, H.: Deep-ocean bottom pressure measurement: Drift removal and performance, J. Atmos. Ocean. Tech., 7, 296-306, https://doi.org/10.1175/15200426(1990)007<0296:DOBPMD>2.0.CO;2, 1990.

Watts, D. R., Sun, C., and Rintoul, S.: A two-dimensional gravest empirical mode determined from hydrographic observations in the Subantarctic Front, J. Phys. Oceanogr., 31, 2186-2209, https://doi.org/10.1175/15200485(2001)031<2186:ATDGEM>2.0.CO;2, 2001.

Whittle, C., Lutjeharms, J. R. E., Rae, D., and Shillington, F. A.: Interaction of Agulhas filaments with mesoscale turbulence: a case study, S. Afr. J. Sci., 104, 135-139, 2008.

Zweng, M. M, Reagan, J. R., Antonov, J. I., Locarnini, R. A., Mishonov, A. V., Boyer, T. P., Garcia, H. E., Baranova, O. K., Johnson, D. R., Seidov, D., and Biddle, M. M.: World Ocean Atlas 2013, Volume 2: Salinity, edited by: Levitus, S. and Mishonov, A., NOAA Atlas NESDIS 74, 39 pp., 2013. 